\title{
A Ciência da Física e a Filosofia: sua possível redução à Filosofia de Aristóteles e de
}

\section{Tomás de Aquino}

The Science of Physics and the Philosophy: its possible reduction to the Philosophy of Aristotle and Thomas Aquinas

\section{La Ciencia de la Física y la Filosofía: su posible reducción a la Filosofía de Aristóteles y Tomás de}

\section{Aquino}

Recebido: 00/01/2022 | Revisado: 00/01/2022 | Aceito: 13/02/2022 | Publicado: 14/02/2022

Fausto Monteiro Mesquita Jr.

ORCID: https://orcid.org/0000-0002-8215-7364 Colégio Rio Branco, Brasil

E-mail: faustinhomesquita@gmail.com

\begin{abstract}
Resumo
Minha tese neste trabalho é a de que a não ser que a Física Moderna (ou, de um modo geral, a Ciência), que está imbuída do método Cartesiano, mude seu método científico para que a Física (teórica e experimental), (ou outra Ciência que venha a "surgir"), possa explicar a Essência do Homem-Natureza, conforme as Filosofias de Aristóteles e de Tomás de Aquino.
\end{abstract}

Palavras-chave: Biologia relativística; Ciência experimental; Essência; Método científico; Teoria do campo unificado.

\begin{abstract}
My thesis in this work is that unless Modern Physics (or, in general, Science), which is imbued with the Cartesian method, changes its scientific method so that it (theoretical and experimental), (or another Science that will "arise"), can explain the Essence of Man-Nature, according to the Philosophies of Aristotle and Thomas Aquinas.

Keywords: Relativistic biology; Experimental science; Essence; Scientific method, Unified field theory.

\section{Resumen}

Mi tesis en este trabajo es que a menos que la Física Moderna (o, en general, la Ciencia), que está imbuida del método cartesiano, cambie su método científico para que la Física (teórica y experimental), (u otra Ciencia que pueda "surgir"), pueda explicar la Esencia del Hombre-Naturaleza, según las Filosofías de Aristóteles y Tomás de Aquino.

Palabras clave: Biología relativista; Ciencia experimental; Esencia; Método científico; Teoría del campo unificado.
\end{abstract}

\section{Introdução}

Conforme Caruso e Oguri (2006, p 01), um dos maiores legados da história da humanidade é a construção do que se pode chamar de cosmovisão científica. O processo de construção desse método corresponde à origem e ao fortalecimento da filosofia e da física na Grécia antiga. Dessa maneira, a cosmovisão científica pode ser entendida como um novo olhar sobre a natureza, ou seja, sobre a physis tal qual era entendida pelos gregos.

É importante compreender que esse momento histórico assinala o início de uma drástica mudança de atividade do homem em relação à physis de grande relevância para o pensamento ocidental, que se refletiria, mais tarde, de forma marcante, na física moderna. É nesse período, riquíssimo, de quase dois séculos, que tem início e se concretiza a ruptura com a concepção mitopoética da natureza, até então predominante, e afirmam-se alguns traços que marcarão a trajetória cultural do ocidente. Por um lado, a busca de uma visão da physis baseada em relações causais estabelecidas a partir da razão, cujo precursor foi Aristóteles, por outro lado, a ideia de simplicidade manifestada desde quando se busca compreender racionalmente a natureza a partir de um único princípio, de uma matéria primordial organizada pela ação dos contrários e finalmente a ideia norteadora de que existe um Cosmos. Para os gregos, Cosmos significa um todo organizado. Podemos dizer que a quebra de paradigma houve 
Research, Society and Development, v. 11, n. 3, e20311326496, 2022

(CC BY 4.0) | ISSN 2525-3409 | DOI: http://dx.doi.org/10.33448/rsd-v11i3.26496

na passagem do mito ao logos.

Esse rico despertar da razão corresponde ao período entre os séculos VII e IV a.C. e teve suas origens na chamada Escola Jônica, cujos primeiros integrantes eram originados da cidade de Mileto, situada no litoral da Ásia Menor. Muitos estudiosos enfatizam que esse é o marco da filosofia europeia. Mas é preciso que fique claro que não há uma linha de demarcação nítida entre o pensamento pré-racional, mítico (ou baseado em concepções antropomórficas) e o pensamento racional, anunciando uma visão científica do mundo. Durante muito tempo vozes das duas correntes de pensamentos coexistiram na tentativa de explicar o cosmos.

Os integrantes da Escola Jônica ocuparam-se basicamente em explicar a natureza física do mundo. A questão de fundo que Tales e tantos outros se colocaram pode ser formulada como: podem todas as coisas serem vistas como uma simples realidade aparecendo em diferentes formas? (Caruso \& Oguri, 2006, p 02)

A característica marcante do trabalho de Tales reside na procura do entendimento da natureza de modo racional, postulando que esteja ligado a um único princípio. Suas ideias são justificadas não em termos de deuses ou forças sobrenaturais, mas em termos da lógica. Desse modo, uma contribuição importante de Tales diz respeito ao desenvolvimento do método da prova sistemática. Para isso ele ensinou como deduzir proposições de axiomas, ou de princípios simples, que pareçam indubitáveis, ingrediente essencial para a racionalização da physis. No contexto intelectual de hoje, marcado pelo pragmatismo e pelo imediatismo, não é demais lembrar que Tales foi movido, principalmente, pela curiosidade intelectual e não por qualquer tipo de necessidade prática, no sentido utilitarista empregado atualmente (Caruso \& Oguri, 2006, p 02-03).

Nota-se que até agora todas as tentativas de formular uma explicação racional para a physis depararam-se com a dicotomia "unidade x variedade". A enorme variedade de coisas e eventos que formam o mundo se contrapõe a qualquer tentativa de entendimento da natureza tendo por base uma unidade. Entender a natureza de forma racional requer o estabelecimento de critérios lógicos, o que implica a busca de uma ordem no mundo, o que por sua vez corresponde ao reconhecimento do que é igual, reforçando a ideia de uma unidade fundamental. E quais seriam as consequências desta postura?

Por um lado, ela poderia levar no limite à convicção da existência de um princípio fundamental, mas ao mesmo tempo apresentaria grande dificuldade para que a infinita variedade de coisas fosse derivada deste único princípio. Esse problema ainda é atual e muito provavelmente é uma barreira epistemológica para as teorias de unificação na Física, como a do campo unificado de Albert Einstein (1919 como citado em Caruso \& Oguri, 2006, p 05).

Com o início da Renascença Italiana surgiu um crescente interesse com relação à natureza. Foi mais exatamente nos séculos XVI e XVII que a ciência natural mudou seu método de investigação. Através de várias descobertas, como as observações astronômicas, que permitiram descrever o aspecto montanhoso da superfície lunar e a revelação de inúmeras estrelas até então desconhecidas, é que começaram a ocorrer inovações na física e na astronomia. É a partir daí, no século XVII, que Galileu Galilei (1632 como citado em Caruso \& Oguri, 2006, p 25-26) começa a explicar os fenômenos através de causas naturais. O interesse em combinar o conhecimento empírico com a matemática, como ocorreu com o trabalho de Galileu, foi o motivo para o surgimento deste novo método científico.

Então, com o surgimento dos trabalhos principalmente de Galileu, houve uma rápida e drástica mudança da cosmovisão do mundo. A physis passou a ter uma visão experimental, passou a ser um problema de medida.

O projeto do Iluminismo é contemporâneo à Renascença. Conforme Grenz, 2008, pp. 14-15, a busca intelectual do ser humano elegera como seu objetivo revelar os segredos do universo para pôr a natureza a serviço do homem, criando assim um mundo melhor. Essa busca culminou na modernidade, cujo empenho tem sido infundir na vida um gerenciamento racional capaz de aperfeiçoar a existência humana por intermédio da tecnologia.

O projeto do Iluminismo traz em seu fundamento algumas suposições epistemológicas. A mente moderna supõe, 
especificamente, que o conhecimento é preciso, objetivo e bom. Além do mais, os modernos supõem que, em princípio, o conhecimento é acessível à mente humana.

A demanda por um determinado tipo de conhecimento faz com que o pesquisador moderno busque um método que demonstre a correção fundamental das doutrinas filosóficas, científicas, religiosas, morais e políticas. O método Iluminista coloca muitos aspectos da realidade sob o escrutínio da razão e avalia aquela com base neste critério. Isto significa que este método crê piamente nas capacidades racionais do ser humano. A perspectiva Iluminista supõe que o conhecimento não somente é exato (e, portanto, racional) como também objetivo.

Conforme Grenz, 2008, pp. 121-122, depois de uma jornada solitária de dez anos pelas montanhas, Zaratustra, aos quarenta anos de idade, decidiu que era tempo de regressar à sociedade dos homens. Chegou a uma cidade próxima da floresta. Quando entrava na aldeia, o eremita que voltava ao convívio dos homens notou que o povo da cidade estava aglomerado no mercado. A esse grupo de pessoas Zaratustra pregou a morte de Deus e a vinda do super-homem.

A publicação de Assim falava Zaratustra (1883), o relato fantasioso de Friedrich Nietzsche sobre os ensinamentos desse personagem legendário, assinalou o começo do fim da modernidade e o início da gestação do período pós-moderno.

O pós-modernismo implica uma rejeição radical do projeto Iluminista, do ideal tecnológico moderno e das suposições filosóficas em que se baseiam. Os adeptos do projeto Iluminista procuram desvelar a unidade central que dá sustentação ao fluxo aparentemente desconexo de toda experiência. Quanto à fonte dessa unidade, os pensadores modernos voltam-se para a cultura humana, a história universal, ou a natureza - acima de tudo, porém, eles começam com a pessoa humana, o eu.

O pós-modernismo acha-se marcado pela rejeição a esse empreendimento. Os pós-modernos chegaram à conclusão de que todas as tentativas de descrever um centro objetivo e unificador - um único mundo real - por trás do fluxo da experiência estão destinadas ao fracasso; no fim, produzem apenas ficção, criações da mente humana. Ao separar a explicação humana da noção de um mundo subjetivo subjacente, a crítica pós-moderna do modernismo (Iluminismo) aparta-nos das coisas e deixanos somente com as palavras. Separa-nos também do ideal Iluminista do eu humano.

Os físicos e suas teorias aqui descritas podem ser encontradas em Alonso \& Finn, 1992. De acordo com Grenz, 2008, pp. 78 a 82, a modernidade nasceu da revolução intelectual. A fagulha da dimensão científica específica dessa revolução foi lançada por Galileu Galilei e atingiu o clímax com Isaac Newton.

A inovação de Galileu consistia em sua tentativa de interpretar o mundo de um ponto de vista estritamente quantitativo, como já foi visto. A experiência que produz resultados quantificáveis (ou seja, números em vez de qualidades não-numéricas) tornou-se a principal técnica da empresa científica emergente. A ênfase nas medições numéricas deu aos cientistas um sentimento de que trabalhavam num campo de pesquisa que produzia conhecimento exato e sem ambiguidades. Organizado em equações, tal conhecimento dá expressão a leis ou padrões no âmbito da própria natureza e, portanto, pode ser usado para predizer outras ocorrências naturais.

O impulso dado por Galileu e Newton levou os pensadores modernos a rejeitarem a visão orgânica do mundo que dominava a antiga compreensão, substituindo-a por uma compreensão mecanicista.

Em meio ao maior de seus triunfos tecnológicos, contudo, determinados aspectos fundamentais da cosmovisão científica moderna foram abalados de dentro para fora. O desafio interno mais devastador veio da física, a disciplina que lhe proporcionara seu mais sólido fundamento. As descobertas em princípios do século XX puseram em dúvida a suposição moderna de que o universo apresentava uma ordem interna consistente, facilmente compreensível e imaginável pela mente humana. O modelo mecanicista, que parecera inquestionável anteriormente, fora submetido a um fogo crescente à medida que acumulavam-se provas de que há no universo muitas outras coisas praticamente indescritíveis e até inimagináveis.

No início do século XX, Max Planck declarou que, no nível atômico, a energia apresenta-se em "pacotes” distintos 
(quanta) e não em fluxo contínuo. Albert Einstein, por sua vez, observou que a luz não é somente uma onda, mas também uma torrente de grupos distintos de energia (fótons).

Paralelamente ao desenvolvimento da teoria quântica, houve uma outra série de descobertas a que me refiro ao título genérico de teoria da relatividade que Einstein solapou a noção aparentemente racional de que o espaço e o tempo são absolutos. Ele refutou a antiga crença de que o comprimento e o tempo podem ser medidos com base em padrões absolutos, como será visto no item 4.

A adesão a um conjunto de procedimentos aceito pela comunidade científica pode nos garantir uma objetividade relativa da parte do observador, mas nenhum relato experimental é capaz de produzir uma observação puramente objetiva e sem envolvimentos.

Os pós-modernos insistem em que não somos espectadores que simplesmente contemplam o mundo, e sim participantes daquilo que procuramos conhecer.

\section{Metodologia}

A metodologia utilizada é a do pensamento reflexivo e a da pesquisa bibliográfica. Pesquiso e reflito sobre este tema desde quando estudava Física na Universidade de São Paulo nos anos setenta.

Em 2017 terminei meu bacharelado em Filosofia na Universidade Federal do Paraná; o que me proporcionou uma maior visão filosófica sobre o contexto deste trabalho. Ao longo desse tempo, percebi que a Física, ou de um modo geral a Ciência Moderna, com seu método experimental, não poderia explicar a Essência do Homem-Natureza.

A partir de então, comecei a pesquisar e fazer anotações a partir de bibliografias, principalmente de Aristóteles e de Tomás de Aquino, como os cinco volumes da Summa Theologiae (Aquino, 1955), a Summa contra Gentiles (Aquino, 1937), El Espíritu de la Filosofia Medieval (Gilson, 1952), os sete volumes da Física de Aristóteles (1831), a Metafísica (Aristóteles, 2012) e o Organón (Aristóteles, 1987). Tais filosofias me permitiram embasar este artigo.

\section{Algumas Reflexões Sobre a Física Experimental}

O mundo é constituído de fatos, fenômenos que nos impressionam. Esses fenômenos não estão aí sem nexos. Por exemplo: existem os fenômenos da física atômica, da física nuclear, da física das partículas, da física do eletromagnetismo, etc. O modo como interpretamos esses fenômenos físicos possibilita a Ciência da Física.

O posicionamento polêmico de como fazer ciência se baseia principalmente nas concepções empírica e racionalista. Tanto no empirismo quanto no racionalismo está a categoria de causalidade. É importante enfatizarmos causalidade, pois é também a partir dela que há a diferença entre física clássica e moderna. Apoiando-se inteiramente em um aspecto filosófico, a ideia de causalidade é indissolúvel de seu efeito: a saber, a mudança de movimento.

Causalidade em seu significado mais geral é a conexão entre duas coisas, em virtude da qual a segunda é previsível a partir da primeira. Historicamente essa noção assumiu duas formas básicas: i) a forma de conexão racional, pela qual a causa é a razão de seu efeito e este é dedutível dela e ii) a forma de conexão empírica ou temporal, pela qual o efeito não é dedutível da causa, mas é previsível com base nela, pela constância e uniformidade da relação de sucessão.

O artigo de Pierre Duhem (1894) trata de experimentos clássicos onde está presente o determinismo. A física moderna (a quântica) contém o decisivo conceito de que na natureza determina-se não a ocorrência de um evento, mas a probabilidade de um evento verificar-se. Acaba assim o determinismo clássico. A mecânica quântica indica pelo menos duas inovações em relação à clássica: i) os papéis fundamentais adquiridos pelo indeterminismo e ii) o estatuto especial atribuído ao ato de medição. Podese dizer que não só na Física, mas também em toda ciência moderna, o problema central está relacionado ao problema da medida. 
Research, Society and Development, v. 11, n. 3, e20311326496, 2022

(CC BY 4.0) | ISSN 2525-3409 | DOI: http://dx.doi.org/10.33448/rsd-v11i3.26496

Assim, a física quântica, com outro estatuto ontológico, representa uma generalização da física clássica, juntamente com a teoria geral da relatividade de Albert Einstein (Alonso \& Finn, 1992) que inclui a física clássica como um caso especial.

Conforme Duhem (1894, p 190), a física experimental faz medições acompanhada de suas interpretações, levando à leis que formam o corpo da física teórica, que pode levar a novas consequências. Como exemplo disso, temos que o físico inglês Paul Dirac (Alonso \& Finn, 1992) previu a existência da anti-matéria, em 1928, quando precisou interpretar um resultado aparentemente sem sentido quando trabalhava com física teórica. A anti-matéria foi depois observada experimentalmente.

O que é uma experiência na física? Uma experiência da física não é simplesmente a observação através de instrumentos de laboratório de um fenômeno. É, além disso, a interpretação teórica desse fenômeno (Duhem, 1894, p. 200).

Em todo experimento estão encadeados: fenômenos, linguagem, hipótese, indução, teoria, lei. Uma experiência da física é a observação precisa de um grupo de fenômenos acompanhada da interpretação desses fenômenos. Essa interpretação substitui os dados concretos realmente recolhidos pela observação por representações abstratas e simbólicas que lhes correspondem em virtude das teorias físicas admitidas pelo observador.

Conforme Duhem (1894, p. 220), o pesquisador observa os fatos e raciocina imediatamente sobre os fatos observados, onde o instrumento matemático representa um papel essencial. Pode-se afirmar que as teorias substituem as propriedades observadas, que são os fenômenos físicos. E as leis experimentais que regem esses fenômenos são trocadas por uma representação simbólica. As teorias físicas são o vocabulário que faz corresponder à cada propriedade física uma grandeza e à cada lei física uma equação. A teoria física e a física experimental são indissociáveis: seria como enunciar uma ideia sem empregar nenhum sinal falado ou escrito. Uma experiência da física nunca pode condenar uma hipótese isolada, mas somente todo um conjunto teórico. Ela reconhece implicitamente a exatidão de todo um conjunto teórico.

A obra de Alonso \& Finn (1992) apresenta um compêndio de teorias físicas. O físico inglês Isaac Newton defendia a hipótese da teoria corpuscular da luz. Por outro lado, o físico holandês Christiaan Huygens defendia a hipótese ondulatória da luz. Ambas as hipóteses abarcavam ampla gama de fenômenos. Explicavam cada uma delas tais fenômenos dentro de seu campo de validade. No entanto, o físico francês Louis deBroglie, com o surgimento da mecânica quântica, fundiu as duas hipóteses com a hipótese de que a cada fenômeno da luz estava associado à um corpúsculo uma onda. E essa hipótese, que se tornou lei, é mais geral porque abarca todos os fenômenos, todas as experiências existentes.

Segundo Duhem (1894, p. 225), o método experimental não pode transformar uma hipótese física numa verdade incontestável, pois jamais se está seguro de haver esgotado todas as hipóteses imagináveis referentes a um grupo de fenômenos. Os resultados das experiências da física são apenas aproximados. O grau de aproximação de uma experiência depende de dois elementos essenciais; que são a natureza e a perfeição dos instrumentos empregados e a interpretação teórica das experiências.

É muito importante analisar se a imprecisão nas medidas é devida aos instrumentos ou é uma incerteza que é característica da própria natureza.

Duhem (1894) distingue na teoria física a definição e a medida das grandezas da física, a escolha das hipóteses, o seu desenvolvimento matemático e o seu confronto com a experiência. Toda lei da física não é verdadeira nem falsa, mas aproximada e provisória, assim como a lei da gravitação universal de Newton, de 1687. Para seu momento histórico, tal lei era verdadeira e incontestável, pois explicava, resolvia e também previa todos os fenômenos físicos da época. No entanto, com o progresso da técnica apareceram novos fenômenos que a lei de Newton não conseguia explicar ou não era convincente. Ela passou a ser um caso especial da Teoria da Relatividade Geral de Albert Einstein que passou a explicar os referidos fenômenos (Alonso \& Finn, 1992). Entretanto, não se pode dizer que a Relatividade Geral seja exata, pois podem aparecer novos fenômenos no futuro que levarão a Relatividade Geral a ser um caso especial de uma outra teoria. 


\section{A Filosofia e o Paradoxo dos Gêmeos da Relatividade Especial}

O filósofo alemão Immanuel Kant (1966) estruturou filosoficamente a física clássica newtoniana. É mister fazer o mesmo com a física moderna de Albert Einstein, criador da teoria da Relatividade e a de Max Planck, criador da física quântica (Alonso \& Finn, 1992). A relatividade corrigiu a física newtoniana para altas velocidades. A física newtoniana para baixas velocidades em comparação com a velocidade da luz no vácuo, que é uma constante e é a máxima velocidade da natureza, é uma aproximação da física da relatividade de Einstein.

A ideia de que as leis da física devem ser as mesmas para observadores que se deslocam uns em relação aos outros em movimento de translação uniforme foi defendida por Galileu Galilei (1996). Esta ideia pode ser apresentada como se segue: se as leis da mecânica são válidas em um dado referencial, então são igualmente válidas em qualquer outro referencial que se mova em translação uniforme em relação ao primeiro, conforme Galileu. Estes referenciais são chamados de inerciais. O princípio da relatividade de Galileu pode ser explicado como apresentado pela Figura 1.

Figura 1 - Transformações de coordenadas de Galileu.

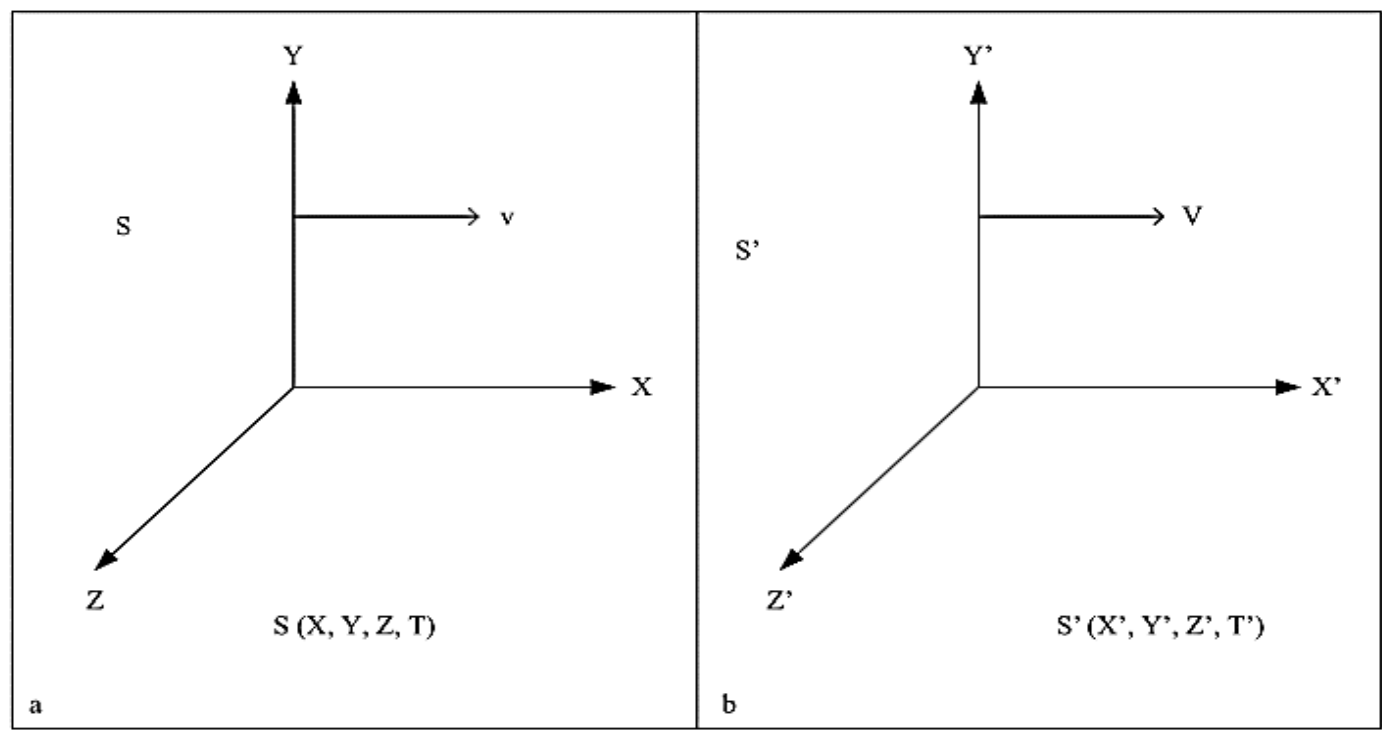

$\mathrm{S}$

Fonte: Autor.

Seja dois referenciais $S$ e $S^{\prime}$. Em $T=T^{\prime}=$ zero, os referenciais $S$ e $S^{\prime}$ coincidem. Seja uma partícula se movendo com velocidade constante, $v=$ constante, no eixo $\mathrm{X}$ quando os referenciais coincidem. A partir daí o referencial S' começa a se mover com $\mathrm{V}=$ cte em relação a $\mathrm{S}$, conforme a Figura 1. As transformações de coordenadas podem ser dadas de acordo com (1), (2) e (3).

$$
\begin{aligned}
& \mathrm{X}^{\prime}=\mathrm{X}-\mathrm{VT}=\mathrm{vT}-\mathrm{VT} \rightarrow \mathrm{v}^{\prime}=\mathrm{v}-\mathrm{V} \quad \mathrm{Y}=\mathrm{Y}^{\prime} \\
& \mathrm{Z}=\mathrm{Z}^{\prime} \\
& \mathrm{T}=\mathrm{T}^{\prime}
\end{aligned}
$$

As equações (1), (2) e (3) são chamadas de transformações de Galileu. Elas subentendem que: i) as escalas de tempo são invariantes $\left(\mathrm{T}=\mathrm{T}^{\prime}\right)$ e ii) as medidas de comprimento também são invariantes. Isso implica que se $\mathrm{L}$ for o comprimento de uma barra em S e L' o comprimento da mesma barra em S', então L' $=$ L. Para baixas velocidades em que $\mathrm{V}<<\mathrm{C}$ (onde C é a 
velocidade da luz no vácuo, é uma constante da natureza e tem o valor bem aproximado de $300.000 \mathrm{Km} / \mathrm{s}$ ), as transformações de Galileu são coerentes. No entanto, para $\mathrm{V} \approx \mathrm{C}$ haverá incoerências.

No eletromagnetismo, as transformações de Galileu não são invariantes; onde as velocidades envolvidas são a velocidade da luz (C) ou muito próxima dela. Como o princípio da relatividade é válido para as leis da física, é preciso encontrar outras transformações que sejam invariantes; quais sejam, as transformações de Lorentz (Alonso \& Finn, 1992).

\subsection{Transformações de Lorentz}

Figura 2 - Transformações de coordenadas de Lorentz.

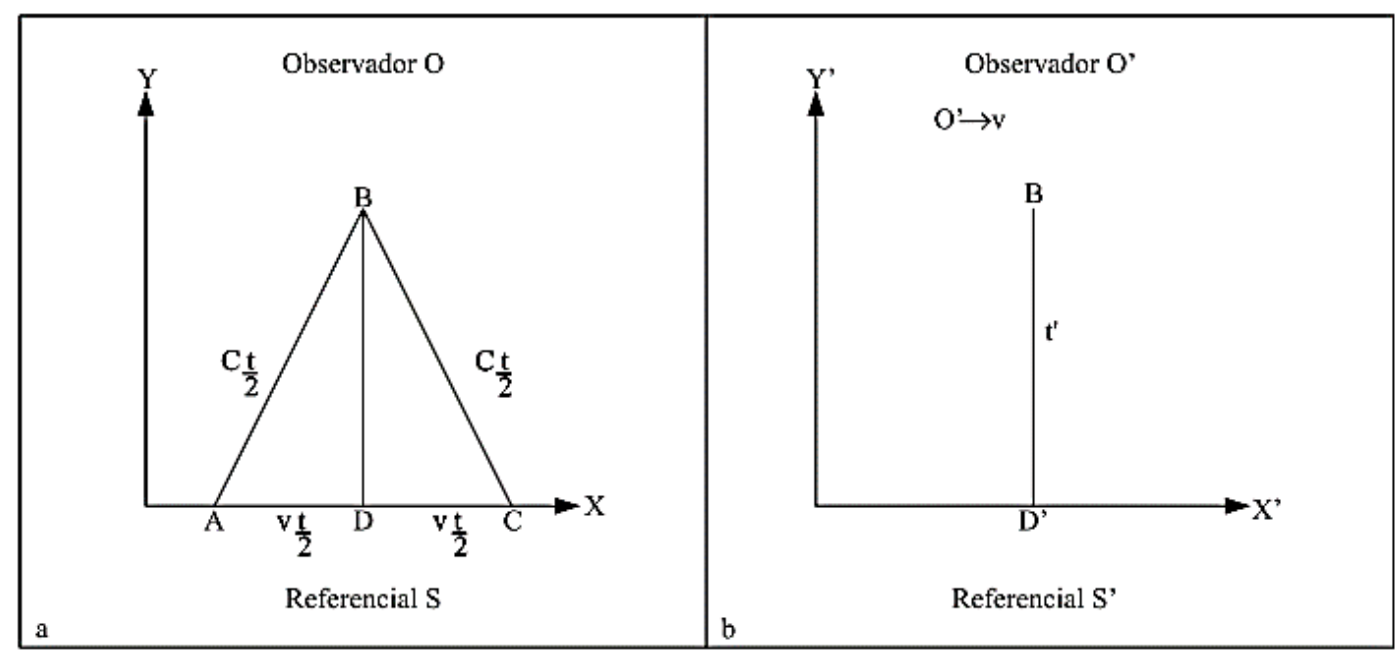

Fonte: Autor.

Seja em $\mathrm{t}=\mathrm{t}$ '=0, onde os referenciais $\mathrm{S}$ e S' coincidem. Então o referencial S' começa a se movimentar no eixo horizontal X' para a direita com velocidade constante V, como indicado na Figura 2. No referencial S' um raio de luz é ejetado na vertical para cima, partindo de D, se reflete em um espelho, posicionado em B, e volta até D'. Supondo dois observadores, O e O', nos referenciais S e S', respectivamente, teremos: i) o observador O’ verá a luz subir e descer após ser refletida, ou seja, verá uma reta vertical de comprimento $2 \overline{B D^{\prime}}$ (Figura 2 b) e ii) o observador O verá a luz descrever uma figura geométrica de um triângulo retângulo com ângulo reto em B (Figura 2a). Sendo t e t' o tempo passado para os observadores O e O', respectivamente, então teremos as equações (4) a (8), abaixo:

$$
t^{\prime}=\frac{2 \overline{B D I}}{C} \quad \text { e } \quad t=\frac{\overline{A B}+\overline{B C}}{C}=\frac{2 \overline{A B}}{C}
$$

Onde:

$$
\begin{aligned}
& \overline{A B}=\overline{B C}=C t / 2 \quad \text { e } \quad \overline{A D}=\overline{C D}=\frac{\text { vt }}{2} \\
& \overline{B D}=\overline{B D^{\prime}}=\sqrt{(\overline{A B})^{2}-(\overline{A D})^{2}}
\end{aligned}
$$




$$
\begin{aligned}
\frac{t^{I}}{t} & =\frac{\overline{B D^{I}}}{\overline{A B}}=\frac{\sqrt{(\overline{A B})^{2}-(\overline{A D})^{2}}}{\overline{A B}} \rightarrow \frac{t^{I}}{t}=\frac{\sqrt{\left(\frac{C t}{2}\right)^{2}-\left(\frac{v t}{2}\right)^{2}}}{\frac{c t}{2}} \rightarrow \\
\frac{t^{r}}{t} & =\sqrt{1-\left(\frac{v}{c}\right)^{2}}
\end{aligned}
$$

Das equações (4) ,(5), (6) e (7), tem-se a equação (8), que é a transformação de Lorentz.

$$
\mathrm{t}^{\prime}=\mathrm{t} \sqrt{1-\left(\frac{v}{c}\right)^{2}}
$$

Onde C é a velocidade da luz no vácuo e $\sqrt{1-\left(\frac{v}{c}\right)^{2}}$ é o chamado fator de Lorentz. Para que as transformações de Lorentz sejam válidas a velocidade da luz (C) tem que ser uma constante na natureza, ou seja, ela é invariante em todos os referenciais.

Da equação (8) podemos inferir que há uma variação do tempo com a velocidade relativa dos referenciais. Por exemplo, se na Figura 2 o referencial S' estiver a uma velocidade relativa a $\mathrm{S}$ de $V=\frac{c}{2}$, teremos $\mathrm{t}^{\prime}=\mathrm{t} \sqrt{1-\left(\frac{\frac{c}{2}^{2}}{c^{2}}\right)}$ resultando em $\mathrm{t}^{\prime}=\mathrm{t}$ $\frac{\sqrt{3}}{2}$

Isto é, se para o observador O passar 1 ano $(t=1)$ no referencial $\mathrm{S}$, para o observador $\mathrm{O}$ ' transcorrerá $\frac{\sqrt{3}}{2}$ anos ou aproximadamente 0,87 anos.

\subsection{Variação espacial}

Figura 3 - Variação espacial.

\section{Observador B}

\section{$\mathrm{A} \longleftarrow \mathrm{v}=$ cte}

Fonte: Autor.

Seja um observador B estacionário em relação ao referencial S e um observador A se movendo em relação a $S$ horizontalmente para a esquerda a uma velocidade constante $(\mathrm{v}=\mathrm{cte})$, conforme a Figura 3. O observador B conclui que o tempo que A percorre é $\mathrm{t}=\frac{L_{F}}{V}$. Então:

$$
\frac{t^{t}}{\sqrt{1-\left(\frac{V}{C}\right)^{2}}}=\frac{L^{\prime}}{V} \rightarrow \frac{V t^{r}}{\sqrt{1-\left(\frac{V}{C}\right)^{2}}}=L^{t} \rightarrow L^{\prime}=\frac{L}{\sqrt{1-\left(\frac{V}{C}\right)^{2}}}
$$


Tem-se assim:

$$
L^{\prime}=\left(\sqrt{1-\left(\frac{V}{c}\right)^{2}}\right)^{-1} L
$$

Aqui L’ é o espaço que o observador O’ mede e L é o espaço que o observador O mede. Se na Figura 3 o observador B medir $\mathrm{L}=1$ metro e se a velocidade relativa do observador A for $V=\frac{c}{2}$, então o observador A vai medir $\mathrm{L}^{\prime}=\frac{2}{\sqrt{3}}$, ou $\mathrm{L}^{\prime} \approx 1,15$ metros.

\subsection{O paradoxo dos gêmeos da relatividade especial}

Como consequência da relatividade especial, onde o espaço e o tempo variam para um observador inercial em relação a outro quando existe um deslocamento de translação uniforme e com velocidade constante (v=cte), pode-se elaborar um paradoxo que ficou conhecido como paradoxo dos gêmeos. Se se tomar a equação (8) e elaborarmos um experimento ideal: sejam Lucas e Luciano gêmeos idênticos e sadios e que estejam ambos em um referencial inercial Delta, sendo a idade de ambos 20 anos em relação a Delta. Agora suponha-se que Luciano fique durante 50 anos Delta se movendo à $99 \%$ da velocidade da luz ( $\mathrm{V}=0,99 \mathrm{C})$, enquanto Lucas fica estacionário em Delta. O tempo para Luciano atingir a velocidade de V=0,99 C e o tempo para ele “voltar" e se encontrar novamente com Lucas são desprezados. Quando eles se encontrarem novamente, Lucas terá 70 anos Delta e Luciano terá 27,1 anos Delta, conforme demonstrado na equação (11).

$$
T_{L}=\left(\sqrt{1-\left(\frac{0,99 C}{C}\right)^{2}}\right) \times 50+20 \rightarrow \quad T_{L}=7,1+20 \approx 27,1 \text { anos }
$$

Pode-se concluir que, enquanto Lucas envelhece 50 anos Delta, Luciano envelhecerá, aproximadamente, 7,1 anos Delta. Seja outro experimento ideal, conforme apresentado na Figura 4.

Figura 4 - Variação espacial.

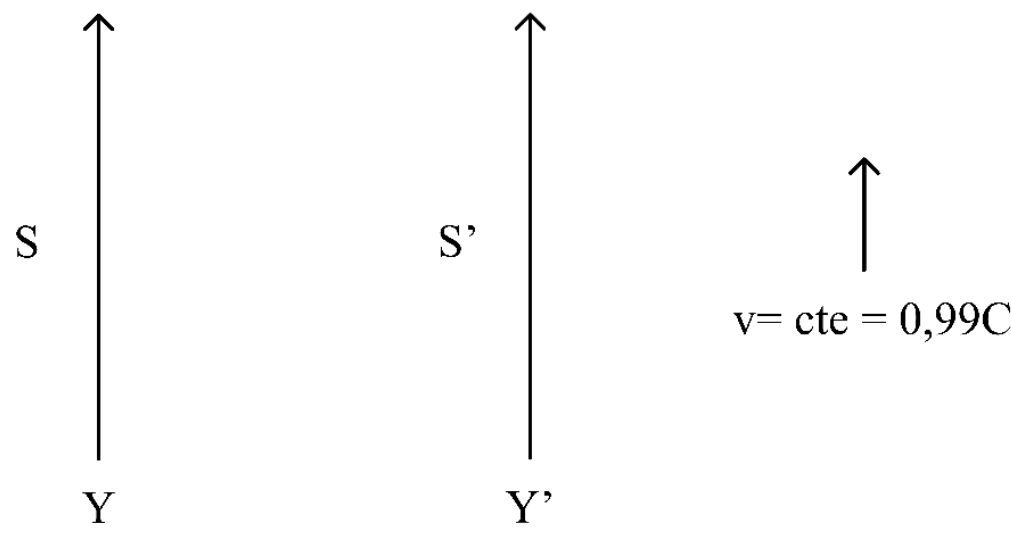

Fonte: Autor.

Sejam as dimensões de Lucas e de Luciano em Y e Y', respectivamente, de 2 metros. Em t=t'=0 os referenciais inerciais 
S e S' coincidem. Supondo que Luciano, em S', está a uma velocidade constante de 99\% da velocidade da luz (v=cte=0,99 C) na vertical e para cima, conforme ilustra a Figura, pode-se concluir que a dimensão de Luciano será de 14,2 metros, conforme demonstração da equação (12).

$$
D_{L}^{\prime}=1 /\left(\sqrt{1-\left(\frac{0,99 C}{c}\right)^{2}}\right) \times 2 \text { metros } \rightarrow D_{L}^{\prime} \approx 14,2 \text { metros }
$$

Imaginemos agora no limite; ou seja, se Luciano pudesse chegar à velocidade da luz (v=C). Segundo as transformações de Lorentz, tem-se:

$$
v \rightarrow C \text {, então } \quad T_{L}^{\prime} \rightarrow 0 \text { e } D_{L}^{\prime} \rightarrow \infty \rightarrow \text { conclusão } 1
$$

O que significa a conclusão 1? Ela quer dizer que se Luciano pudesse viajar à velocidade da luz (C), o tempo pararia para ele, ou seja, ele não envelheceria; e caso ele permanecesse por um tempo infinito na velocidade C, tornar-se-ia imortal. Isso significa também que Luciano teria dimensão infinita.

Nesse momento tocamos no ponto nevrálgico do texto. Foi mencionado que os experimentos de Lucas-Luciano eram ideais. Mas o que é um experimento ideal e real? Antes de responder a esta pergunta, precisa-se questionar o que é ideal e o que é real. Ao ideal não se pode atribuir realidade objetiva (existência). Ideal é uma perfeição concretizada mas não realizada, que se verifica toda vez que se acentua a separação entre o dever ser e o ser. Já o real indica o modo de ser das coisas existentes fora da mente humana ou independentemente dela. Existe uma relação entre real e ideal; já que o oposto de real é ideal, que indica o modo de ser daquilo que está na mente humana e não pode ser ou ainda não foi incorporado ou atualizados nas coisas.

Foi mencionado que agora temos dois paradoxos filosóficos, que são o não envelhecimento de Luciano e sua dimensão infinita quando ele está na velocidade da luz em relação a Lucas. Estes paradoxos são ideais, pois Luciano não pode se mover na velocidade da luz, porque há um impedimento físico. O impedimento físico ocorre porque sua massa sendo finita, para ele chegar à velocidade da luz, necessitaria de uma energia infinita. Essa conclusão pode ser vista na relação entre massa e energia da física da relatividade, conforme a equação (14).

$$
E=\frac{m_{0} C^{2}}{\sqrt{1-\frac{V^{2}}{C^{2}}}}
$$

Onde $\mathrm{m}_{\mathrm{o}}$ é a massa de Luciano quando ele estiver em repouso em relação a Lucas no referencial inercial $\mathrm{S}$. Se $\mathrm{V}_{\text {Luciano }}$ = C, então sua energia se torna infinita, conforme demonstração da equação (15).

$$
E=\frac{m_{0} C^{2}}{\sqrt{1-\frac{C^{2}}{C^{2}}}} \rightarrow E=\frac{m_{0} C^{2}}{\sqrt{1-1}} \rightarrow E=\frac{m_{0} C^{2}}{0} \rightarrow \infty
$$

Ou então:

$$
\begin{aligned}
& m(v)=\frac{m_{0}}{\sqrt{1-\frac{C^{2}}{C^{2}}}} \\
& \text { Se } V_{\text {Luciano }}=C \rightarrow m_{\text {Luciano }} \rightarrow \infty .
\end{aligned}
$$


Foi mencionado que elaboramos o experimento Luciano-Lucas como sendo ideal. Porque experimento ideal? Porque é uma perfeição concretizada, mas não realizada. Fica assim a separação entre o dever ser e o ser. O dever ser é o ideal representado por Luciano na velocidade da luz e o ser é a não possibilidade de ele atingir esta velocidade. Por quê realidade? Porque existe para Luciano a impossibilidade física dele chegar à velocidade C. Mas Luciano pode chegar à velocidade de v=0,99C em relação ao referencial $\mathrm{S}$. E para ele chegar à velocidade de v=0,99C tem-se um imenso problema técnico.

Só para se ter uma ideia da energia necessária para levar Luciano à v=0,99C, tomemos a equação (14). Suponhamos que Luciano tenha uma massa inercial quando $S=S^{\prime}$ de $M o=20 \mathrm{~kg}$. Conclui-se conforme a equação (14) que precisaríamos de uma energia de 128 x 10Ex(17) joules, conforme demonstra a equação (17). Esta quantidade de energia é muito grande; ou seja, é possível fisicamente mas inviável na prática. Assim sendo é um experimento ideal e não real.

$$
E=\frac{20 x(300.000)^{2}}{\sqrt{1-\frac{(0,99 C)^{2}}{C^{2}}}} \approx 128 \times 10 E \times 17 J
$$

Agora vamos comparar o valor de aproximadamente $10 \operatorname{Ex}(18)$ joules com a energia necessária para fazer um elétron atingir esta mesma velocidade; ressaltando que a massa do elétron em repouso é estimada em 9,11 x 10Ex(--31) quilogramas. Incluindo esse valor na equação (14), tem-se que a energia necessária será de 5,8 x 10Ex(--13) joules para colocar o elétron nesta velocidade, conforme fica demonstrado através da equação (18).

$$
E=\frac{9,11 \times 10^{-51} x(300.000)^{2}}{\sqrt{1-\frac{(0,99 C)^{2}}{C^{2}}}} \approx 5,8 X 10 \mathrm{Ex}-13 \text { Joules. }
$$

A ordem de grandeza entre a energia para Luciano e para um elétron atingir essa velocidade é de aproximadamente $10 \operatorname{Ex}(31)$ vezes maior. Conclui-se desta maneira que a experiência Luciano-Lucas é ideal, impraticável.

\subsection{Biologia relativística}

Por outro lado, como é fisicamente possível Luciano chegar à velocidade $\mathrm{v}=0,99 \mathrm{C}$ e se se tomar a experiência de Luciano a essa velocidade em relação ao referencial inercial Delta onde Lucas envelhece 50 anos e Luciano aproximadamente 7,1 anos Delta (como ficou demonstrado), pode-se questionar por quê biologicamente ele deixa de envelhecer. Deve haver um por quê biológico da diferença de idade entre eles. A pergunta que surge é: por quê fisiologicamente, bioquimicamente Luciano deixa de envelhecer?

Sugiro assim a criação de uma ciência que chamo de Biologia Relativística para explicar esse porquê.

\subsection{O paradoxo dos gêmeos e a filosofia de Kant}

Para Immanuel Kant, na sua obra Crítica da Razão Pura (1966), númeno e fenômeno são conceitos filosóficos. O fenômeno é a coisa tal como aparece a nós. O conhecimento científico é universal e necessário; mas é fenomênico. O númeno é a coisa como ela é em si. Da mesma maneira como há um para mim, deve haver um para si. Nós devemos nos contentar por necessidade com a ilha que habitamos; e que não existe outro terreno sólido para construirmos uma casa.

Esse território é precisamente o do conhecimento fenomênico que é o único conhecimento seguro. Pode-se afirmar que a intuição do homem é fenomenotizante e que admite um substrato metafenomênico; ou seja, numênico. O conceito de númeno 
não contém contradições, e, portanto, como tal, nós podemos pensa-lo mas não conhecê-lo efetivamente. Além do mais, númeno é um conceito-limite que serve para circunscrever as pretensões da sensibilidade.

Conclui-se, dessa maneira, que Luciano à velocidade da luz é o númeno. E ele até o limite, ou seja, bem próximo de C, onde ele tem seu envelhecimento retardado, é o fenômeno que pode ser pensado e conhecido. É o fenômeno que por problemas técnicos não pode ser realizado.

\subsection{O estudo da natureza e do movimento em si com aplicação ao paradoxo dos gêmeos}

Tendo como exemplo o movimento de Luciano na natureza no paradoxo dos gêmeos, passa-se a estudar o que é natureza, tendo como substrato o movimento em si. Segundo Aristóteles (2012), as quatro causas da natureza (material, formal, eficiente e final) têm como princípio o movimento. No caso da viagem de Luciano, a causa material é o próprio Luciano, a causa formal é "vir-a-ser" de Luciano no incremento da sua velocidade, a causa eficiente é o "motor" externo que eleva a velocidade de Luciano e a causa final é a possibilidade de Luciano chegar à velocidade próxima da luz. E, caso ocorresse dele chegar à C, o tempo pararia para ele.

\subsubsection{A natureza e o movimento}

O conceito de forma procede da física ou filosofia da natureza. A palavra física provém do termo physis que significa natureza. Segundo os filósofos gregos o que define a natureza é o movimento. No "Segundo Livro da Física”, Aristóteles (1831, p. 1192b21) afirma que pertencem à natureza aquelas coisas que "parecem possuir um princípio intrínseco de movimento". O sentido de movimento é bastante amplo. Não se trata apenas do movimento local, mas também, por exemplo, as mudanças de cor, de temperatura, de consistência, o nascimento, o crescimento e a morte dos seres vivos.

Ao se afirmar que a natureza possui um princípio intrínseco de movimento, isto quer dizer que não é o agente exterior que provoca o movimento. Para determinar os princípios intrínsecos do movimento, Aristóteles procede da seguinte maneira: qualquer coisa que passe por uma mutação está se tornando alguma coisa a partir da negação dessa coisa. Assim, o branco se torna branco a partir do não branco. Não basta, porém, a existência de dois contrários apenas, mas também um terceiro princípio que é o sujeito desses contrários.

Segundo Chatelet (1982, pp. 200-220), Aristóteles chama de término para o qual tende o movimento de forma para o qual tende o movimento; ou simplesmente forma - a qual inere em um sujeito.

\subsubsection{A substância}

Deve-se considerar a hipótese de que em algumas transformações da natureza possam ocorrer não apenas a passagem de uma forma para a privação dessa forma ou vice-versa, conservando-se o sujeito, mas também que o próprio sujeito possa torna-se outro sujeito.

Considere-se agora esse novo sujeito; seja ele quem for. Poderá ser ou não ser capaz de mudanças. Se possuir qualquer determinação identificável, necessariamente poderá sofrer algum tipo de mutação, porque se ele, sendo determinado, é tal ou qual coisa, poderá vir a se tornar algo que não seja esta tal ou qual coisa.

Se ele possuir alguma determinação deverá ser composto de sujeito e forma. Este outro sujeito também se possuir alguma determinação deverá, igualmente, ser composto de sujeito e forma. E assim por diante, até chegarmos a um sujeito que seja inteiramente indeterminado. Esse primeiro sujeito inteiramente indeterminado que se deve postular na natureza para poder explicar o movimento é o que Aristóteles chama de matéria primeira.

A matéria primeira enquanto tal não pode existir por si só. De onde se conclui que a matéria primeira, devido a sua total 
Research, Society and Development, v. 11, n. 3, e20311326496, 2022

(CC BY 4.0) | ISSN 2525-3409 | DOI: http://dx.doi.org/10.33448/rsd-v11i3.26496

indeterminação, pode existir somente em potência e que não existe em ato. Para ser algo e existir, a matéria primeira precisa receber uma determinação mínima que lhe será dada por uma forma primeira. Esta forma primeira que fará a matéria primeira existir em ato é chamada de forma substancial. O composto formado pela matéria primeira e pela forma substancial é o que na filosofia aristotélica se chama Substância ou Ser.

Segundo Aristóteles, a matéria primeira não só não pode ser identificada pelos sentidos humanos ou por instrumentos de laboratório como também pela inteligência humana. Só pode ser conhecida indiretamente; por analogias. Por que se ela fosse determinada pelos sentidos humanos ou por instrumentos de laboratório não seria mais matéria primeira.

$\mathrm{Na}$ física de Aristóteles, matéria e forma são princípios intrínsecos do movimento. Mas somente os dois não explicam o movimento.

O primeiro princípio extrínseco que deve ser admitido para poder explicar o movimento é o que se chama de causa eficiente. A causa eficiente é a causa externa que produz efetivamente o movimento. O movimento enquanto tal implica em uma passagem do ser em potência ao ser em ato. Não é possível que a mesma coisa esteja simultaneamente em ato e potência segundo o mesmo aspecto. Portanto, é impossível que segundo o mesmo aspecto e segundo o mesmo modo, algo seja movente e movido; isto é, que se mova a si mesmo. Portanto, tudo que é movido deve ser movido por outro.

Toda causa eficiente para agir como tal tem que estar em ato. Isto ocorre por causa de uma determinada forma a qual também confere uma pré-determinação para o modo de agir desta causa eficiente.

Segue-se assim que todos os movimentos da natureza são necessariamente ordenados a algum fim. $\mathrm{O}$ fato facilmente observável de que agentes naturais semelhantes sempre agem de modo semelhante é indício de que a natureza se comporta em seus movimentos com uma ordenação a algum fim. Logo, a natureza é necessariamente teleológica em seus movimentos, conforme Chatelet (1982, pp. 200-220).

\subsubsection{Conclusão}

Dessa maneira, pode-se concluir no estudo de "O estudo da natureza e do movimento em si" que a Substância da metafísica de Aristóteles é "Luciano na velocidade da luz". Todo o estudo do "O estudo da natureza e do movimento em si" corrobora a "viagem de Luciano". Segundo Santo Agostinho:

Não sabia que Deus é espírito, não algo cujos membros se estendam em altura ou largura, nem algo que tenha uma massa, porque uma massa é menor na parte do que no todo e, se for infinita, é menor numa sua parte de extensão determinada do que no infinito e não está inteiramente em toda parte como espírito, como Deus. E ignorava totalmente o que está em nós, segundo o qual somos, e somos definidos com razão, nas Escrituras, imagem de Deus. (Agostinho, 2017, p. 85-86).

Agora algumas perguntas são necessárias; tais como: Como seria, como ficaria o pensamento de Luciano quando ele estiver viajando em relação à quando ele estiver estacionário; ou seja, quando $S$ '=S? E quando ele estiver em $S$ ' à velocidade relativa de $0,99 \mathrm{C}$, quais seriam os processos de acontecimentos, de eventos que lhe ocorreriam? Quando ele voltasse ao referencial Delta S, poderia relatar os acontecimentos, os eventos vividos?

Na metafísica de René Descartes (2018) existe a separação entre coisa extensa e coisa pensante. Ou, pensamento e matéria. No nosso contexto, temos a "res cogitans" e a "res extensa" de Luciano e Lucas.

Santo Agostinho (1995) já havia teorizado o cogito. Em polêmica com os céticos, Agostinho havia observado que "se duvido, existo". A dúvida é uma forma de pensamento e esse por sua vez não é concebível fora do ser.

Enquanto o cogito de Agostinho (1995) revela Deus, o cogito de Descartes (2018) revela o homem, ou melhor, as exigências que devem marcar o seu pensamento. Enquanto que em Agostinho o cogito se arquiteta ao se referir a Deus, porque 
nele se funda, em Descartes, adquirida a verdade da própria existência, é necessário partir para a conquista do real diverso do nosso eu. Mas o que entende Descartes por pensamento? Segundo ele:

Com o termo pensamento, abranjo tudo aquilo que existe em nós de tão factual que sejamos imediatamente conscientes dele, como por exemplo, todas as operações da vontade, do intelecto, da imaginação e dos sentidos são pensamentos. E acrescentei imediatamente para excluir tudo aquilo que disso deriva: assim por exemplo um movimento voluntário tem como seu ponto inicial o pensamento, mas ele próprio não é pensamento (Descartes, 2018, p. 31).

Nenhuma metafísica ou lógica atual pode responder como será, como ficará o pensamento de Luciano quando estiver viajando ou quando ele estiver próximo à velocidade da luz, como por exemplo, v=0,99C em S'. Esta é uma filosofia que tem que ser elaborada para o futuro; da mesma maneira que Kant construiu um sistema filosófico para a física newtoniana, como descrito no início deste trabalho.

\section{O Método Científico}

Conforme Keller:

Somos seres orientados para o futuro, e assim, precisamos entender a nós mesmos como seres em uma história que leva a algum lugar, a uma finalidade, a termos esperança. Os povos antigos costumavam enxergar o tempo e a história como algo cíclico. A teologia cristã concebe a história como algo linear, levando ao 'dia do juízo final', ou a um progresso com um controle tecnológico sobre a natureza. (Keller, 2018, p. 235).

O sistema lógico que alicerça o processo científico foi apresentado - em sua primeira versão - por Francis Bacon no século XVII (Rossetti, 2018). Atuando em trabalhos feitos por outros autores, como por exemplo, Al-Hazen - 600 anos antes o método de Bacon exige que os cientistas façam observações, formem uma teoria para explicar o que foi observado e depois teste a validade de suas respostas a partir de experimentos. Assim, se forem verdadeiros, os resultados poderiam então ser enviados para revisão e constatação de outros cientistas.

Enquanto Aristóteles não via a necessidade de experimentações ou as deixava em segundo plano, Platão acreditava que as verdades seriam alcançadas quando um número de homens suficientemente intelectuais as estruturassem depois de muitas discussões. Bacon os criticou, pois não faziam uso de experimentos, processo no qual estariam as provas do mundo real. Bacon tem vários trabalhos chaves, sendo dois deles o "Novum Organum" (1620) onde apresenta os pilares do método científico e o "Nova Atlântica" (1623) que retrata uma ilha fictícia onde há pesquisas focadas em invenções (Rossetti, 2018).

O "Novum Organum” é uma das seis partes que constitui a obra de Bacon denominada "Instauratio Magna”, traduzida como a grande restauração, onde Bacon procura desenvolver o seu pensamento filosófico-científico. Segundo Rossetti (2018), William Hepworth Dioxon, um dos biógrafos de Bacon, defende que a influência desse autor no mundo moderno é tão grande que todo homem que anda num trem, envia um telegrama, senta-se em uma poltrona, atravessa o Atlântico deve a Bacon alguma coisa.

Bacon aprendeu a desprezar o aristotelismo e defendia que a filosofia deveria ser ensinada pelo seu verdadeiro propósito, e para tal um novo método de investigação deveria ser concebido. Com essa concepção, Bacon deixou a universidade e tentou descrever um procedimento racional para estabelecer a causação entre fenômenos na indução. A indução para Bacon foi, no entanto, radicalmente diferente da empregada pelos aristotélicos (Rossetti, 2018).

Bacon sugeriu no "Novum Organum" que outra forma de indução deveria ser concebida além da empregada por Aristóteles. Ela deveria ser usada para provar e descobrir, não somente os primeiros princípios, mas também os axiomas menores e descobrir tudo o que fosse possível. O método baconiano baseou-se em relatar experimentos para eliminar teorias alternativas, 
que pelo uso de instrumentos e o conhecimento da natureza, o homem pudesse governar ou direcionar a natureza para produzir resultados definitivos.

Assim, ao buscar o conhecimento da natureza, o homem alcança poder sobre ela e restabelece o "império do homem sobre a criação", que havia sido perdido pela "queda" junto com a pureza original do homem. Bacon, levando em consideração a possibilidade da humanidade abusar do seu poder sobre a natureza adquirido pela ciência, expressa sua opinião de que não havia a necessidade de temê-lo, pois uma vez que a humanidade restaurasse o poder que lhe foi atribuído por Deus seria certamente governado pela "razão correta e religião verdadeira” (Rossetti, 2018).

Sabe-se que vários nomes da ciência, como Robert Grosseteste, Galileu Galilei, Francis Bacon, René Descartes, Robert Boyle, Isaac Newton e outros buscavam na ciência uma forma de compreender a natureza. Ressalta-se que desde a Idade Média, a natureza não era mais vista como os gregos o faziam na Antiguidade (a natureza [physis] explica a si mesma, se apresentando sob o signo da constante mudança), mas como criação divina e testemunho da existência de Deus. Muitos desses cientistas beberam não somente da religião, mas também do esoterismo (Netmundi, 2021).

Isaac Newton acreditava que por meio da alquimia poderia compreender como Deus faz para manter toda a matéria unida e que a gravidade era uma criação exclusivamente divina, como declarado em "General Scholium” (Rossetti, 2018).

O método científico atual não é baconiano e se deve muito mais a Descartes. Todavia, elementos importantes do método científico apareceram com Francis Bacon e em autores anteriores a ele, como Galileu, que ressaltava a importância da experimentação; Grosseteste, que destacou o quão é importante as anotações da replicação dos experimentos por terceiros; Roger Bacon, que afirmou que apenas o argumento não é suficiente, sendo fundamental a experimentação; Newton, que agregou o método empírico-indutivo e o racionalista-analítico-dedutivo. (Rossetti, 2018)

Além dos autores citados, houve outros com destacada importância na história da ciência e da filosofia, retornando até Aristóteles.

Em 1637, Descartes (Netmundi, 2021) publicou o texto que pode ser considerado a certidão de nascimento da filosofia moderna; ou seja, o "Discurso do método para bem conduziu a razão e buscar a verdade nas Ciências". O projeto cartesiano está desde o início pautado por essa busca de uma maneira a reparar o conhecimento seguro do incerto ou de uma forma de tornar sólidas novas crenças, de modo a que se possa pretender ao status de conhecimento. Outra indicação importante é a crítica da tradição cultural, incapaz de satisfazer àquela intenção.

De todas as disciplinas tidas como Ciência, apenas a matemática mostra-se promissora "devido à certeza e à evidência de suas razões" (Netmundi, 2021). Por fim, esse autor afirma a fé em seu método que segundo Descartes "agindo assim, não existirão verdades tão distantes que não possam ser alcançadas, nem tão escondidas que não sejam descobertas” (Netmundi, 2021). Descartes descreve o método científico como “jamais aceitar como verdadeira coisa alguma que não esteja tão clara à minha mente que não reste dúvida de sua verdade; dividir cada dificuldade em tantas partes quanto possível e necessária para resolvê-las; organizar meus pensamentos, iniciando pelos assuntos mais fáceis e simples e progredindo gradativamente para os mais complexos; fazer, para cada caso, enumerações e revisões até que esteja certo de não ter omitido nada.” (Netmundi, 2021)

Nossa forma de pensar atual é ainda cartesiana; ou seja, tudo deve passar por um método, ser explicado e avaliado racionalmente para, somente então, fazer parte do conjunto de nossas crenças. Esta forma de pensar mesclou o método indutivoempírico de Bacon com o método dedutivo-racional de Descartes (Netmundi, 2021; Rossetti, 2018).

\section{A Possível Redução da Física Moderna à Filosofia nas Visões de Aristóteles e de Tomás de Aquino}

Partindo de todas as considerações apresentadas neste trabalho, acredita-se que há embasamento para questionar se poderá um dia a Física, tal como está estruturada hoje, chegar ao conhecimento da Inteligência Maior. Infelizmente não, posto 
que ela possui em si mesma uma descrição de suas próprias limitações. É neste contexto que se tenta mostrar filosoficamente que o conhecimento total através da Ciência não é possível. Comecemos formulando uma pergunta a um ilustre discípulo cristão dos filósofos gregos, Santo Agostinho, a fim de que possamos questionar filosoficamente qual o sentido da Física de hoje em dia: e quanto a nós, sobre Agostinho, haveremos de permanecer aqui esperando pelo dia em que a Física compreenda e explique a "Essência do Homem-Natureza" e a supere?

Esta pergunta é pertinente, pois o método científico utilizado pela ciência atualmente, que é o cartesiano, está estruturado de tal maneira que permite a pergunta. Ela poderá ser respondida, ou seja, a Ciência poderá compreender e explicar a "Essência do Homem-Natureza" se houver uma mudança de método científico.

\subsection{Finalidade da vida humana}

Para se conceber qual a "finalidade da vida humana", tem-se que questionar e responder às indagações: "o que sou?", "de onde vim?”, "para onde vou?", “o que faça no mundo?".

Vou tentar responder à pergunta inicial, ou seja, qual a finalidade da nossa vida no mundo com uma metáfora. Imaginemos que um adulto ao sair de sua casa sofra um acidente na rua e em consequência perca todo o seu conhecimento. Quando voltar a si, qual a pergunta que fará? Qual será sua preocupação imediata? Não será certamente sobre a natureza ou a utilidade dos objetos que vê ao seu redor.

A sua pergunta será uma interrogação total: “o que aconteceu? “, “onde estou?”, "por que estou aqui?”, “o que sou?”, “como é a natureza?". Ora, a situação do homem neste mundo é de algum modo semelhante, pois viemos ao mundo sem que nos explicassem previamente essas perguntas. Porém, como não nascemos no estado adulto, nossa inteligência vai se formando aos poucos e, ao mesmo tempo, vamos nos acostumando às coisas até vê-las como algo natural.

Contudo se nascêssemos no estado adulto, nossa perplexidade seria semelhante à daquele homem que perdido todo seu conhecimento ao sofrer o acidente acordasse num lugar desconhecido. Assim nossa inteligência, quando atingimos o estado adulto, vai formulando perguntas que em cada caso se fazem necessárias.

Construímos, então, com o passar do tempo a Ciência que procura a Verdade, pois temos inteligência. Em um primeiro levantamento é essa a finalidade da vida humana: buscar e Contemplar a Verdade!

\subsubsection{O que é a filosofia}

Entre os gregos chamou-se de filosofia ao estudo da essência de cada uma das realidades, a ordenação de todas estas realidades entre si em um todo organizado através de uma rede de causalidades e a dependência destas redes de causalidades a uma primeira causa à qual se subordinam todas as demais causas.

Meu texto vai principalmente versar nas filosofias de Aristóteles e de Tomás de Aquino; e os referidos filósofos se enquadram no que se chama de Filosofia Perene. É importante mencionar que esta filosofia tem como representantes mais conhecidos: Platão, Aristóteles, Santo Agostinho, São Tomás de Aquino. Ou seja, a maioria dos filósofos gregos, patrísticos e medievais. Além destes, mais uma multidão de outros pensadores posteriores e mesmo contemporâneos. Na filosofia perene, a Contemplação desempenha um lugar central com a busca pela Verdade.

\subsubsection{O que é a vida}

Nos escritos da Filosofia Perene, os seres vivos são apresentados como aqueles entes que são pela sua própria natureza capazes de produzir movimentos imanentes. Entende-se por movimentos imanentes aqueles que, por contraposição, não são transeuntes. Um movimento transeunte é aquele que passa de um ente a outro; ou seja, aquele pelo qual um ente move a outro 
ente. Um movimento imanente é aquele que permanece no próprio ente; ou aquele pelo qual um ente é capaz de mover a si mesmo.

São seres vivos aqueles que são pela sua própria natureza capazes de moverem a si mesmos. São seres inanimados aqueles que são capazes de mover a outros e são incapazes de moverem a si próprios. Neste sentindo, a vida é a capacidade de mover-se a si mesma ou a capacidade de produzir um movimento imanente.

Existe um princípio metafísico segundo o qual nada pode mover-se a si próprio e tudo o que é movido deve ser movido por outro. O movimento de cada ser vivo possui uma causa externa. O fato do ser vivo mover a si próprio não significa que algo externo não cause o movimento interno do ser vivo. O ser vivo não se move a si mesmo no sentido de que ele seja a causa última de seu movimento e que este movimento não tenha uma origem externa.

Se tudo o que se move deve ser movido por outro, para que um ser vivo mova a si mesmo, uma causa externa deve desencadear o movimento do ser vivo de tal maneira que o próprio ser vivo cause a partir disto um movimento interno a si mesmo. Se não se tratasse de um ser vivo, a causa externa faria com que o ente movido produzisse um movimento transeunte, e não imanente.

Todo ser vivo apesar de sua unidade que deriva de sua forma substancial única deve ser composto de partes não homogêneas. Quando se diz que um ser vivo move-se a si mesmo, quer-se com isto dizer que o ser vivo é composto de partes heterogêneas e que uma parte do ser vivo move a outra parte. Portanto, em cada ser vivo existe uma parte que move e outra distinta que é movida. Se um ser vivo fosse constituído por uma única parte indistinta haveria contradição com o princípio segundo o qual tudo o que é movido é movido por outro; pois, neste caso, a mesma única parte que move também deveria ser movida. As partes que constituem um ser vivo, ademais, não podem ser homogêneas porque a parte motora deve estar em ato para o movimento e a parte movida deve estar em potência para o movimento e, portanto, devem ser necessariamente partes distintas e não homogêneas. Um ser vivo, por conseguinte, se deve ser algo capaz de mover-se a si mesmo deverá ser constituído necessariamente por partes heterogêneas. Por exemplo, uma gota d'água ou mesmo uma grande quantidade de água jamais poderia ser viva.

\subsubsection{A alma como forma substancial do corpo}

Colocadas as coisas desta maneira, para que algo possa estar vivo ele deve poder por sua própria natureza mover a si mesmo. Isto implica em primeiro lugar que tanto a parte movente como a parte movida do ser vivo devem compartilhar a mesma natureza, pois, se não fosse assim, o movimento não seria imanente mas transeunte. Isto é, se a parte movente e a parte movida tivessem naturezas diferentes, ambas constituiriam dois entes diversos e o movimento estaria passando de um ente a outro, em vez de permanecer no mesmo ente.

A unidade de natureza entre as partes do ser vivo implica em uma unidade de forma substancial. Logo, fica a conclusão de que não pode haver movimento imanente se não houver unidade de forma substancial entre as partes movente e movida. Mas isto implica, também, que o movimento imanente pelo qual se define a vida deve provir da própria forma substancial que dá unidade ao ser vivo. Caso contrário, não seria por sua própria natureza que ele seria capaz de mover a si mesmo.

É importante ressaltar que assumimos que cada coisa possui uma natureza específica por causa de sua forma substancial e esta capacidade de mover a si mesmo provém desta forma substancial, como de sua causa formal.

Desta maneira, chega-se à forma substancial dos seres vivos, de seu princípio vital, de seu princípio animante ou simplesmente de sua alma, que é aquilo que anima os seres vivos. É por este motivo que nos escritos de Aristóteles e de São Tomás de Aquino define-se alma como sendo "a forma substancial do corpo físico que tem potência à vida" (Rosa, 2001, p. 4). 


\subsubsection{Contextualização da filosofia}

O ser, o movimento e a verdade são os três princípios de que a filosofia se utiliza para a construção de uma síntese do Universo. O primeiro destes princípios consiste na afirmação de que a realidade primeira das coisas é o seu existir ou o seu ser. A mesma coisa dita de outra maneira diz que o primeiro princípio da Filosofia sustenta que algo existe e que o existir ou o ser deste algo é enquanto tal sua realidade primeira da qual dependem todas as demais realidades. Ele é primeiro porque é o pressuposto último de qualquer conhecimento, não demonstrável a partir de quaisquer outros princípios mais elementares.

O segundo princípio da Filosofia é a realidade do movimento, definido enquanto tal a partir do conceito de ser. O segundo princípio afirma que este ente que pressupomos como existente pode mover-se. E mover-se para este princípio significa mais do que mudança de lugar. Supomos que algo se move quando aquilo que é, também pode ser outro. E esta possibilidade de transformar-se em realidade é quando se dá o movimento.

Supor o movimento implica em pressupor que não somente o ser é uma estrutura básica do Universo, mas também o poder ser. A possibilidade de construção de uma síntese da estrutura do Cosmos na Filosofia pressupõe a existência de três realidades fundamentais: o ser, o poder ser e a inteligência que apreende o ser e o poder ser. Ao apreender o ser, a inteligência capta aquilo que se chama de o terceiro princípio, a saber, a verdade.

A postulação da verdade como estrutura básica do Universo é necessária sob pena de retornarmos às ciências experimentais, onde a consciência é impossível, ou sob pena do retorno à filosofia moderna na qual se postula a consciência, mas não é possível alcançar o mundo exterior.

Este terceiro princípio sustenta apenas que quando a inteligência apreende o que é o ser, o conteúdo desta apreensão corresponde realmente àquilo que o ser confere aos entes que existem. Negar este princípio equivaleria a sustentar que apesar de se ter afirmado como princípio que algo existe, poderia acontecer que de fato nada existisse.

\subsubsection{Realidade última}

A ideia de que existe uma realidade além do mundo material da qual seu movimento e por conseguinte sua estrutura dependam, pode ser difícil de ser aceita por quem foi educado, seja ele cientista ou não, pelos estabelecimentos de ensino modernos, impregnados pela ideia de que a ciência experimental é a descrição exata e última da estrutura Cósmica. Mas é muito simples apreender o contrário.

É imensamente fácil perceber que existe algo além do Universo tal qual nos é descrito pela Física. A consciência humana é o primeiro exemplo deste algo. Dizer que a consciência humana é algo existente e que se situa além do universo descrito pela Física é o mesmo que dizer que jamais será possível elaborar um programa de computador que seja capaz de perceber sua existência. Ou seja, que ele tenha consciência de si mesmo.

Qualquer pessoa que tenha um mínimo de experiência em programação percebe o quão evidente é esta afirmação. Pelos mesmos motivos não é possível construir um robô, não importa o quão complexo ele possa ser, que fosse capaz de apreender sua própria existência enquanto tal. Se o fosse, em pouco tempo ele também apreenderia seus direitos e exigiria não ser desligado.

Tais coisas, porém, não passam de ficção científica. Qualquer programador ou engenheiro sabe que não existe nenhuma via possível para escrever um programa ou construir uma máquina que tenha consciência de sua existência. A impossibilidade anterior monstra o quanto há algo atuando no universo extenso além dos princípios propostos pelas ciências experimentais e que, portanto, não se pode invocar a priori uma impossibilidade de que o Universo extenso não possa sofrer a ação de causas que se situem além de sua natureza. 
Research, Society and Development, v. 11, n. 3, e20311326496, 2022

(CC BY 4.0) | ISSN 2525-3409 | DOI: http://dx.doi.org/10.33448/rsd-v11i3.26496

\subsubsection{Elementos básicos da filosofia da natureza}

Segundo os filósofos gregos, a natureza é um princípio intrínseco de movimento. Deve-se notar que esta afirmação não diz apenas que a natureza é um princípio de movimento, mas também que é um princípio intrínseco de movimento. Deseja-se com isto dizer que o princípio de movimento do qual se afirma ser a natureza não é o agente exterior que provoca o movimento.

Conforme veremos mais adiante o agente ou princípio exterior não apenas existe, como também será necessário que exista. Aqueles que acostumaram a pensar sobre a estrutura da natureza com base apenas nas ciências experimentais certamente terão dificuldade em compreender como entidades que não poderão jamais serem vistas nem detectadas por nenhuma experiência de laboratório possam não apenas ser reais, como também ser o próprio fundamento de toda a natureza.

Para os que cultivam as ciências experimentais é uma afronta afirmar que a estrutura básica que dá realidade aos entes sejam entidades puramente inteligíveis e que, por isso mesmo, jamais poderão cair sob o domínio destas ciências. Estas pessoas tendem a negar ou pelo menos a não reconhecer a realidade do que não possa ser identificado pelo método experimental. No entanto, segundo a Filosofia Perene, não somente existem entidades deste tipo, como inclusive são entidades mais fundamentais da natureza e da realidade. Nada mais poderia existir se elas não existissem.

\subsubsection{Realidades que transcendem o método experimental}

Examinando o funcionamento da vista, será fácil perceber que ele não apreende a existência dos entes, mas apenas acidentes, como por exemplo, suas cores e os seus formatos. O sentido da vista não garante que a pessoa que estamos vendo seja um ser efetivamente existente. Poderá tratar-se de um sonho, de um holograma ou de uma alucinação. O que os olhos veem é apenas a cor e o formato dessa pessoa; não a sua existência. O mesmo pode ser dito do ouvido. Por este sentido pode-se ouvir o som que algo produz; mas não a existência deste algo.

Porém, sabe-se que os entes que nos cercam existem e que esta existência é uma realidade. Não o sabemos por causa dos sentidos nem dos instrumentos de laboratório, que não ultrapassam os limites dos sentidos. A consciência do real é um longo trabalho de abstração da inteligência. Nós temos consciência de que as coisas existem porque em algum momento do nosso desenvolvimento a experiência sensorial tornou-se suficientemente rica e a inteligência tornou-se suficientemente madura para que tal abstração tivesse tornado capaz de apreender o que é ser real e não real.

A partir do momento em que a inteligência se torna capaz de apreender abstratamente o que é ser em ato, torna-se também possível que no homem surja a consciência de que alguma coisa individualmente considerada seja real. Esta consciência ocorre quando as informações que chegam ao homem pelos sentidos são confrontadas com outras anteriores; e a rica coerência destes dados obriga a inteligência a explicá-los atribuindo às coisas vistas e ouvidas a realidade do ser em ato que ela já havia tornado capaz de apreender.

Por este motivo, a experiência da consciência da realidade não é uma experiência sensorial, mas uma experiência essencialmente intelectiva, abstraída e sobreposta aos dados dos sentidos. Somente um ser dotado de inteligência pode possuíla. Nunca uma máquina irá possuí-la, nem um instrumento de laboratório, nem um computador.

Por mais elaborados que sejam, o grau de consciência da realidade destes instrumentos é e sempre será nulo. Os sentidos e os instrumentos de laboratório nunca passam de formas acidentais. Este raciocínio mostra que há algo, como é o caso da existência dos entes que nos circundam, cuja realidade é tão óbvia, e que, não obstante isso, não pode e não poderá nunca ser apreendida nem pelos sentidos nem por instrumentos. Trata-se de uma realidade que está além das possibilidades das ciências experimentais, além dos sentidos e dos instrumentos e possui uma natureza puramente inteligível. 


\subsubsection{Princípios extrínsecos do movimento}

$\mathrm{Na}$ física de Aristóteles, a matéria e a forma são os princípios intrínsecos necessários para explicar o movimento. No entanto, somente eles não explicam inteiramente como o movimento é possível. Para isto, devem ser acrescentados também outros princípios extrínsecos.

O primeiro princípio extrínseco que deve ser admitido para poder explicar o movimento é o que se chama causa eficiente. A causa eficiente é a causa externa que produz efetivamente o movimento. Quando uma pessoa empurra uma mesa, ela é a causa eficiente do movimento da mesa. Quando a água de uma panela ferve, o fogo é a causa eficiente desse aquecimento.

Segundo a Física de Aristóteles, tudo o que se move deve ser movido necessariamente por uma causa eficiente externa. Esta afirmação pode ser demonstrada do seguinte modo: o movimento, enquanto tal, implica em uma passagem do ser em potência ao ser em ato. Antes de iniciar-se o movimento, o ente móvel está, no que diz respeito à forma para a qual tende o movimento, apenas em potência.

O ente móvel, na medida em que está em potência, possui uma relação de possibilidade para com o ato que lhe será determinado pela forma, mas não possui ainda nenhuma determinação em ato que lhe será conferida pela forma. $\mathrm{O}$ desencadeamento do movimento, no entanto, já é um início desta determinação e pressupõe, portanto, que o processo desta determinação já tenha se iniciado. Não pode ter-se iniciado, porém, apenas pela potência, porque isso significaria que aquilo a que se chamava potência já possuía alguma determinação e que, portanto, não seria apenas potência.

O movimento, por conseguinte, já teria se iniciado, ao contrário do que havia sido suposto. O início do movimento, portanto, já supõe uma primeira determinação da potência que não pode provir dela mesma. Esta primeira determinação, tendo características de ato, e não de potência, não pode provir do próprio móvel. Deverá vir de um movente externo que deverá possuir a determinação necessária para iniciar o movimento. Isto é, deverá provir de um movente externo que, ao contrário do móvel, esteja em ato. Portanto, nada pode mover-se a si mesmo, mas apenas por um agente externo em ato ao qual se chama de causa eficiente. Se não existisse a causalidade eficiente, apenas pela matéria e pela forma como princípios intrínsecos do ente movido, o movimento não seria possível.

\subsubsection{A causalidade final}

No caso de São Tomás de Aquino, o problema dos fins é ontológico. Isso porque o mundo em que o homem está inserido possui uma ordenação intrínseca independente da subjetividade do homem, e a ordenação está ligada a um fim, segundo Tomás. A ordem que Tomás descreve como existindo no Universo implica necessariamente a existência de Deus, que é por sua vez a causa final desta ordem.

Dessa maneira, o problema da ordem e do fim não é mais cosmológico, mas metafísico. Deve-se, assim, acrescentar agora que apenas a causalidade material e formal, como princípios intrínsecos, e a causalidade eficiente, como princípio extrínseco, não são suficientes para explicar completamente o movimento. Para tanto deve-se acrescentar, como já afirmado anteriormente, a causalidade final.

Toda causa eficiente para agir como tal tem que estar em ato. Isto ocorre por causa de uma determinada forma a qual também confere uma pré-determinação para o modo de agir desta causa eficiente. Segue-se daqui que todos os movimentos da natureza são necessariamente ordenados a algum fim. O fato facilmente observável de que agentes naturais semelhantes sempre agem de modo semelhante é indício de que a natureza se comporta em seus movimentos com uma ordenação a algum fim.

A palavra que em grego significa fim ou finalidade é teles. Diz-se por isso que a natureza é necessariamente teleológica em seus movimentos. Assim entendida, a causalidade final é a causa que move a causa eficiente, a qual, por sua vez, move o composto cujos princípios intrínsecos são a causalidade material e a formal. 
Destaca-se que a causa final é a causa de todas as outras causas, ou simplesmente a causa das causas e é neste sentido também a verdadeira explicação última do movimento. Segundo esta concepção última da natureza, essencialmente teleológica, só se poderá dizer que o movimento é verdadeiramente conhecido quando for possível explicá-lo por meio da causa final, e não quando apenas se identifica a causa eficiente (Rosa, 2001).

\subsubsection{Substância}

Tudo o que se move é constituído, como de seus primeiros princípios reais, de matéria prima e de forma substancial. Os compostos de matéria e forma substancial, juntamente com os seus primeiros acidentes, estes últimos necessários para que os entes compostos possam interagir com o mundo à sua volta, são chamados de substâncias.

Segundo Aristóteles,

O sentido primário mais verdadeiro e estrito do termo substância é dizer que é aquilo que nunca se predica de outra coisa, nem pode achar-se em um sujeito. Como exemplo de substância podemos colocar um homem concreto ou um cavalo concreto. (Rosa, 2001, p.59)

\subsubsection{Essência}

Segundo o que São Tomás de Aquino afirma em sua obra De Ente et Essentia, chama-se Essência algo comum a diversas naturezas pelo qual os entes são classificados em suas várias espécies. A Essência pode ser entendida de duas maneiras diversas. Num certo sentido é o princípio de conhecimento e em outro sentido é aquilo pelo qual os entes possuem o ser. Deste modo, a forma substancial unindo-se à matéria produz a essência, que é o ente em potência (Rosa, 2001, pp. 71-73).

\subsubsection{Prova da existência de Deus através da primeira via de São Tomás}

Santo Tomás afirma e demonstra que há cinco vias para provar-se a existência de Deus. A primeira via que vamos mostrar é a mais manifesta. É aquela que procede da análise da existência do movimento de todas as coisas. Nesta prova, Tomás chega à conclusão de que deve existir uma causa primeira do movimento de todas as coisas, a qual chamamos Deus.

De acordo com São Tomás na sua obra a “Ordem dos Conceitos” tem-se:

Na verdade, só é movido o que está em potência para aquilo para que é movido; e só move o que está em ato. Com efeito, mover é fazer passar algo de potência para ato; e nada pode fazer passar algo de potência para ato senão aquilo que está em ato; assim o quente em ato, o fogo, faz passar a madeira, que é quente em potência, a quente em ato - e, deste modo, a move e altera. Porém, não é possível que a mesma coisa esteja simultaneamente em ato e em potência debaixo do mesmo aspecto, mas só em aspectos diversos: aquilo que está quente em ato não pode estar, ao mesmo tempo, quente em potência - pode, no entanto, estar simultaneamente frio em potência. É, pois, impossível que um ser seja, ao mesmo tempo e do mesmo modo, movente e movido - ou que um ser se mova a si mesmo. Portanto, tudo aquilo que é movido é necessariamente movido por outro. Se, pois, aquilo que move um ser é também movido, forçoso é que também ele seja movido por outro - e este, por outro: aqui, porém, não se pode proceder até ao infinito; pois, nesse caso, não haveria um primeiro movente e, por conseguinte, também não haveria nenhum outro movente: porque os segundos moventes só movem se também eles forem movidos pelo primeiro movente - tal como o bordão não move senão porque também ele é movido pela mão. Somos, pois, forçados a chegar a um primeiro movente que não é movido por qualquer outro. É este que entendem ser Deus. (Rosa, 2001, p. 60).

\subsubsection{Determinismo, contingência, acaso}

Existe na ciência da Física um conceito chamado entropia, a qual mede o grau de desordem de um sistema. O princípio do aumento de entropia mostra um aumento da desordem no Universo. Pode-se utilizar este resultado para definir uma "seta do tempo": o futuro é a direção em que a entropia tende a aumentar; ou seja, o grau de desordem (o acaso) tende a aumentar no 
Research, Society and Development, v. 11, n. 3, e20311326496, 2022

(CC BY 4.0) | ISSN 2525-3409 | DOI: http://dx.doi.org/10.33448/rsd-v11i3.26496

Universo, evoluindo espontaneamente sem "intervenção extrema". Isto é, ordem tende à desordem. (Nussenzveig, 2002, p. 232)

Um ser vivo (conforme estudado no item 6.1) é um sistema altamente improvável segundo a biologia, e sua existência parece à primeira vista violar o princípio do aumento da entropia. É o que ocorre com o ser vivo: ele sobrevive graças à produção de moléculas orgânicas com grau de ordem elevado pelo processo de fotossíntese, que é alimentado pelo Sol. Na entropia está implícito o movimento que estamos estudando até agora.

Como conciliar o determinismo com o acaso, com a contingência segundo a filosofia de Aristóteles e de São Tomás?

Como vimos, quatro são as causas. Entretanto, é necessário ainda acrescentar algo muito importante: na filosofia de Aristóteles é possível um agente causar por acidente uma transformação para a qual ele não era movido por causalidade final?

Quando isto ocorre, diz-se que o efeito ocorreu por acaso (foi o que se analisou acima); ou, quando o agente era uma causa inteligente, o acaso também recebe o nome de sorte. Estas circunstâncias quando ocorridas são consideras causas por acidente. Os efeitos terão uma causa eficiente, mas que não causará estes efeitos per se, mas por acidente.

$\mathrm{O}$ efeito per se de uma causa natural é aquele que se lhe segue de acordo com as exigências de sua forma. $\mathrm{O}$ efeito per se de uma causa inteligente é aquilo que ocorre tendo em vista a intenção do agente. Ambos os tipos de causas podem causar um efeito por acidente quando se tratarem de efeitos que estejam unidos acidentalmente ao efeito causado per se pelo agente.

Na causalidade costuma ocorrer, entretanto, que as coisas que se dão pela sorte ou pelo acaso, ou seja, além do âmbito da causa final em uma determinada linha de causalidade, possam ser reduzidas a alguma causa superior que ordena as causas inferiores que pareciam operar por acaso. Quando isso acontece do ponto de vista da causa superior, a aparente causalidade do efeito das causas inferiores já não pode mais ser vista como verdadeiro acaso.

Isto se deve não à existência de causas per se que operavam em uma linha paralela de causalidade, mas à própria linha de causalidade que parecia operar por acaso apenas porque a análise se limitava à ação das causas inferiores (Rosa, 2000, pp. 94-95).

\subsubsection{A Física e a Inteligência Maior e outras inteligências}

Se a Física supuser que existe uma Inteligência Maior e que a Natureza não se assemelha a uma grande máquina, ela estará dizendo que aquela não aparece como uma intrusa ocasional no reino da Natureza. Ao contrário, a Física deve começar a suspeitar que essa Inteligência Maior é a criadora e governadora da Natureza - não sem dúvida a inteligência humana, mas a que existe na Natureza da qual a nossa inteligência brotou. Quando é dito, repetindo Parmênides, que o Ser e o Pensar são uma e só coisa, conclui-se que esta é a condição sine qua non para a inteligência. Em última análise, é graças a essa capacidade de uma inteligência em se identificar que a faz inteligente.

É importante salientar quando uma inteligência adquire a reflexão. Exemplificando com o Homem, a reflexão ocorreu porque para ele toda etapa sucessiva sempre contém e transcende de uma etapa anterior. Porém, esta transcendência é toda especial: não apenas o Homem transcende a etapa precedente como também toda a inteligência que a produziu.

Por este motivo, o Homem pode se colocar do lado de fora dessas etapas. Há um modo de evoluir que parece se direcionar segundo um programa com a tendência a uma ligação com a Inteligência Maior.

Se um dia o Homem através da Física conseguir chegar ao conhecimento total da Natureza seria possível explicá-la totalmente. Desse modo, perguntamos: o Homem se identificaria por completo com essa Inteligência Maior? Tento mostrar, desde o início do presente trabalho, que nos domínios da Ciência atual, que essa identificação não é possível. Ou seja, o conhecimento total não é possível, a não ser que a Ciência atual mude seu método de investigação.

Faça-se uma analogia entre a teoria física da Relatividade de Albert Einstein e a afirmação acima de que não podemos chegar ao conhecimento da Inteligência Maior - o "fora" e o "dentro" - o objetivo e o subjetivo. Segundo a teoria da Relatividade 
nenhum ser material que possua massa pode chegar à velocidade da luz no vácuo. Já foi analisado este assunto no item 4. Isso quer dizer que existe um limite para que o subjetivo (ou o "dentro") se torne o objetivo (ou o "fora").

Caso o ser humano chegasse à velocidade da luz, o subjetivo (que é o ser humano) tornar-se-ia o objetivo (que é a Natureza). No entanto, segundo a Relatividade, tal fato não é possível.

Já afirmei que minha tese é a de que a não ser que a Ciência atual mude seu método de investigação, ela não poderá ter o conhecimento total da Natureza; ou seja, identificar-se com a Inteligência Maior explicando a "Essência do Homem-Natureza".

O método científico atualmente utilizado é o cartesiano, conforme demonstrado no Item 5.

Conforme Santo Agostinho:

O que amo, então, quando amo meu Deus? Quem é aquele que está acima da cabeça de minha alma? Subirei até ele pela minha própria alma. Ultrapassarei minha faculdade pela qual me junto ao corpo e preencho de vida seu organismo. Não é nessa faculdade que encontro meu Deus: com efeito, ela se encontra até no cavalo e no jumento, que não compreendem, e é a mesma por que vivem também seus corpos. (Agostinho, 2017, p. 262)

Segundo Philippe:

Graças à virtude da sabedoria, a inteligência humana adquire uma certa conaturalidade com o termo da sua contemplação: a substância primeira. Esta virtude da sabedoria, virtude suprema, estabelece entre Deus e nós, entre a inteligência divina e a nossa uma certa semelhança que nos permite levar a mesma vida que Deus e conduzi-la como uma vida que nos é conatural e não estranha e penosa. Graças à conaturalidade que a sabedoria estabelece entre a inteligência primeira e a nossa inteligência, este ato de contemplação pode-se expandir na alegria. Ele é plenamente deleitável. (Philippe, 1949, p. 538-539)

\subsubsection{Natureza e inteligência}

Faça-se antes de mais nada, um comentário entre os significados de Natureza e inteligência. A Natureza é o objeto de toda inteligência por que aquela é inteligível. Em sentido mais específico, diz-se como inteligível o ser que pode ser entendido ou compreendido. No seu significado próprio e específico, o termo natureza indica o ser das coisas enquanto existe fora da mente humana ou independentemente dela. Já a expansão Inteligência Maior significa o ser do qual não se pode pensar nada de maior.

\subsubsection{Análise Aristotélica de causa}

Já foi estudado o conceito de causa Aristotélica ao longo deste texto. Causa, no sentido mais geral, é tudo que intervém positivamente na constituição de uma coisa existente. Por isso, a causa influi na própria coisa existente, colocando nela algo que a partir daí pode ser nela encontrado. Na Natureza não existem um amontoado de entes; mas uma ordenação de entes que são ligados por nexos de causalidade.

No sentido mais geral, causalidade é a lei que permite a conexão entre duas coisas, em virtude da qual a segunda é univocamente previsível a partir da primeira. Aristóteles afirma que a relação entre conhecimento e ciência consiste em ter em conta as causas; nada havendo fora disto.

Perguntar a causa de uma coisa é o mesmo que perguntar o porquê dessa coisa. A causa é por que uma coisa existe. Por exemplo, o bronze é a causa da estátua. Por outro lado, a causa pode ser também a Essência necessária ou a Substância de uma coisa. Por exemplo, é a causa do Homem a natureza intelectiva ou racional que o define.

A doutrina de Aristóteles demonstra a estreita conexão entre a noção de causa e a de Ser. A causa é o princípio da inteligibilidade. Porque compreender a causa significa compreender a articulação interna de um Ser. Isto é, a razão pela qual um Ser, como por exemplo, o Homem, Deus ou uma pedra, são o que são e não podem ser ou agir diferentemente. 


\subsubsection{Ciência e Verdade}

Já afirmei no item 6.1 deste texto que a ciência busca a Verdade. No entanto, o que é a Verdade? São Tomás de Aquino define a Verdade como uma adequação da inteligência e do ser que ela o apreende. Isto é, a Verdade ocorre quando há uma identificação entre o conteúdo de uma inteligência que apreende um ser e o próprio ser. Não se deve esquecer, entretanto, que se mantém o teorema aristotélico de que as coisas e não a Inteligência Maior são a medida da Verdade. Ou seja, a Inteligência Maior está apta a medir; porém não é medida.

As coisas (ou os outros seres) estão aptas a medir e serem medidas. Existe assim também uma Verdade nas coisas: aquilo pela qual as coisas se assemelham ao seu Princípio; que é a Inteligência Maior ou Deus. A causa da verdade nas inteligências inferiores está no objeto. No entanto, na Inteligência Maior a causa da Verdade está nEla própria. Isto é, Ela é a Verdade.

\subsubsection{Leis científicas e Inteligência Maior}

Feitas essas considerações, questionamos: podem existir leis científicas a partir das quais a Física tal como está estrutura atualmente possa chegar a explicar a Inteligência Maior? Para existirem tais leis é preciso provar que a Inteligência Maior é inteligível para a Física como está formulada hoje. Caso contrário, a Física precisa encontrar outro método científico para que possa explicar a Causa Primeira ou a Inteligência Maior.

É preciso encontrar um Ser Imaterial. Primeiramente, Aristóteles constata que os seres vivos observáveis na natureza podem ser classificados segundo uma hierarquia de modos de vida. Nas plantas somente existe o modo de vida correspondente ao princípio vegetativo, que é o responsável pelo alimento e pelo crescimento. Nos "animais imperfeitos", além do princípio vegetativo, existe também o sentido; mas não o movimento de um lugar para outro. É o caso das ostras, por exemplo. Nos “animais perfeitos", além dos princípios vegetativo e do sentido, encontra-se também o movimento.

Finalmente no Homem, além dos três atributos acima, encontra-se também o intelecto. Nos seres vivos de hierarquia mais alta estão incluídos todos os atributos encontrados nos de hierarquia mais baixa; mas não vice-versa.

Como já foi visto ao longo do texto, Aristóteles pontua que o que é comum a todo sentido (segundo ele, existem cinco sentidos até hoje considerados: visão, audição, paladar, tato e olfato) é o fato de que eles recebem a forma sem a matéria. Por exemplo, a cera recebe o sinal de um anel sem considerar se ele é de ouro ou de alumínio. Estes cinco sentidos convergem para um comum. Deste modo, unificam-se em uma informação única. O prolongamento no tempo das informações obtidas pelos sentidos sem usá-los, segundo Aristóteles, é a imaginação.

\subsubsection{Imaginação e Intelecto}

Acima da imaginação está o Intelecto. O Intelecto é a faculdade pela qual o Homem apreende a Essência das coisas ou dos seres. Aquilo que cada ser é em sua espécie, abstraídas as condições individuais. Como foi afirmado acima, a operação dos sentidos recebe a forma sem a matéria. Ou seja, esta operação resulta numa abstração sobre o sensível. A operação do intelecto, tendo por objeto este produto da operação dos sentidos, resulta numa abstração ainda maior.

$\mathrm{Na}$ interpretação de Tomás de Aquino, Aristóteles ao dizer que quando a operação do sentido recebe a forma que existe no sensível, porém sem a matéria, está afirmando que através da informação contida nos impulsos nervosos que saem do nervo ótico ou então o relato de um observador a respeito das cores que está vendo, pode-se reconstituir o objeto colorido. É por este motivo que por meio da Ciência conseguimos chegar à Lua, inventar o celular e assim por diante; ou seja, termos construído tecnologias.

Agora se chega a um ponto importante: quando se analisa a forma abstraída pela inteligência do objeto sensível que lhe 
Research, Society and Development, v. 11, n. 3, e20311326496, 2022

(CC BY 4.0) | ISSN 2525-3409 | DOI: http://dx.doi.org/10.33448/rsd-v11i3.26496

é apresentado pela imaginação, a informação ali contida não é a forma de um objeto material. Como exemplo, se se considerar que a essência apreendida de homem é um ser racional, o que se pode reconstituir? Se fosse reconstituir o ser apreendido pela abstração da inteligência de "Homem", ter-se-ia que reconstituir um Ser Imaterial; ou seja, um Homem Imaterial.

A inteligência é capaz de ver o imaterial. E isto que ele vê não está na natureza; mas nela mesma, pois existe este Ser e Ele próprio é imaterial. Quando se afirma este fato, deve-se basear em Parmênides (Chatelet, 1982, vol. 1) que afirma que o ser e o pensar são uma e só coisa.

Podemos concluir então que este Ser Imaterial é o Ser Primeiro, a Causa Primeira, a Inteligência Maior ou Deus. Tanto quanto se pode inferir, ou concluir, até o presente estágio da Física de hoje não se pode reconstituir esta Inteligência Maior.

A Física de hoje tirou de seus domínios a causa final da Natureza.

\section{Teoria do Campo Unificado}

Na Física atual existe um conceito chamado teoria do campo unificado.

Em física, um campo é uma grandeza física que possui um valor associado em todo ponto do espaço. Por exemplo, pode-se falar de campo gravitacional que atribui um "potencial gravitacional" a cada ponto do espaço. As isotermas mostradas diariamente nos boletins meteorológicos são uma imagem de um "campo de temperatura" na superfície terrestre.

Os campos podem ser quantidades estruturadas, isto é, formadas por diversos componentes. Assim, por exemplo, o campo gravitacional é um campo vetorial, como o campo elétrico e magnético, quantidades que associam três valores a cada ponto do espaço em cada instante de tempo - a saber, as suas componentes num dado sistema de coordenadas (SEARA, 2021; UNESP, 2021).

Não é meu objetivo fazer um tratado sobre Campo. Além do mais, o que foi escrito é o suficiente para se ter noção do mesmo quando falarmos de Teoria do Campo Unificado. Uma bibliografia importante sobre teoria do campo é a de Landau \& Lifshitz (1973).

Depois de formular a Teoria da Relatividade Geral em 1915, na qual mostrou a relação entre a geometria e a gravitação, Einstein começou a pensar na possibilidade de haver também uma relação entre a geometria e o eletromagnetismo e com isso geometrizar a física; isto é, unificar a física.

É necessário afirmar que naquela época só eram conhecidas duas forças na natureza: Força Gravitacional Newtoniana e Força Eletromagnética Maxwelliana. Com a descoberta de mais duas forças na Natureza, como a força nuclear fraca pelo físico ítalo-norte-americano Enrico Fermi em 1934 e a força nuclear forte pelo físico japonês Hideki Yukawa em 1935, a ideia de unificar todas as quatro forças da natureza: gravitacional; eletromagnética; nuclear forte e nuclear fraca, se tornou mais complicada. Embora as forças eletromagnética e fraca (força eletrofraca) estejam unificadas, o problema de hoje é unificar as forças quânticas eletrofraca e forte com a força gravitacional (Infopédia, 2021).

Resumindo: o que os físicos de hoje buscam é unificar estas quatro forças no que se chama Teoria do Campo Unificado; o qual teria uma única "Estrutura Lógica", uma única Lei. Com esta única "Estrutura Lógica", todos os fenômenos físicos seriam explicados. Pergunto: só físicos?

O que quero fazer é uma analogia entre a teoria do campo unificado - com sua única estrutura lógica - com a Inteligência Maior do meu texto. Talvez esta unificação ainda seja possível para o futuro. Porém, tal unificação não diria qual a "Essência do Homem-Natureza", como ficou exprimido ao longo do texto.

Fica assim também subentendido depois de tudo que foi tratado através deste trabalho, se as leis que representam e explicam os fenômenos da natureza, exprimem realmente e totalmente estes fenômenos. 


\section{Considerações Finais}

Os homens de Ciência que mais têm afinidade para com estas disposições capazes de levar o homem à sabedoria provavelmente são os físicos teóricos, como aqueles que se dedicam ao estudo da relatividade e a busca da teoria do campo unificado. Entretanto, apesar do modo como estas questões são colocadas entre os físicos teóricos, muito faz lembrar as disposições iniciais do homem sábio.

O modo como os físicos e outros cientistas têm colocado estas questões é tal que já de partida restringem as possibilidades de resposta; e isto ocorre por duas razões. A primeira razão está em que, direta ou indiretamente, os físicos não estão dispostos a aceitar senão aquilo que possa ser verificado pelo método experimental. Ora, isso significa negar o caráter inteligível do Cosmos, pois os instrumentos de laboratório responsáveis pela experimentação não são mais do que um prolongamento da vida sensorial do homem.

Uma atitude semelhante a esta é a de descartar todo conhecimento que não possa ser expresso em números, ou pelo menos forçar todo conhecimento a ser expressado matematicamente. Ora, os números não ultrapassam nas coisas o nível da quantidade, que é uma característica material; um conhecimento de objetos puramente inteligíveis, portanto, não pode ser enquadrado nem na categoria da experimentação nem na categoria da expressão matemática por uma questão de exigência intrínseca.

Quando os homens de ciência pretendem, pelo apresentado, que as repostas às suas indagações se enquadrem ao critério da verificação por um experimento de laboratório ou ao critério da quantização matemática estão com isso automaticamente impedindo que suas perguntas os conduzam àquele conhecimento que a filosofia denomina de sabedoria, que transcende inteiramente o nível sensorial e da quantificação numérica.

Expressa-se muito bem a este respeito Lauand (1987):

É importante destacar a diferença entre ciência e cientificismo: cientificismo é uma posição filosófica, e não científica, que considera válido somente o conhecimento científico. A ciência e a técnica, hoje, deslumbram tanto que quase não se questiona uma mentalidade como a representada por uma posição como esta. Aplicando à esta sentença de Lord Kelvin, que afirma que "todo conhecimento que não pode ser expresso em números, é de qualidade pobre e insatisfatória", e ao cientificismo em geral o seu próprio critério de avaliação, resulta que também ela, e o cientificismo em geral, é de qualidade pobre e insatisfatória, pois tal sentença não se deixa expressar em números. Pieper investe contra as filosofias que pretendem que o único conhecimento com sentido e conteúdo seja o que se possa expressar em enunciados protocolares. Ele afirma que só podemos expressar, protocolar numericamente realidades de menor importância. (Lauand, 1987, p. 113-116)

Mas tem-se ainda, além desta, outra razão pela qual as questões levantadas pelos físicos, não obstante a sua semelhança com as perguntas que se fazem os sábios, não podem conduzi-los à sabedoria. É que os físicos delimitam previamente o campo em que se dispõem a buscar suas respostas à própria área da Física. À primeira vista pode parecer natural que tenha que ser assim; dentro da metodologia de cada ciência em particular, esta atitude pode ser até justificável. Porém, o fato é que, justificável ou não, deixa de ser verdade que, ao mesmo tempo, uma atitude como esta não pode conduzir à sabedoria, nem à contemplação.

O sábio não põe limites à sua busca; pelo contrário, ele tem que estar aberto para a totalidade do conhecimento seja qual for o campo de origem da pergunta que tenha sido seu ponto de partida. Ainda segundo Lauand (1987):

Para aquele que indaga pelas conexões totais, pelo último significado do mundo e da existência, ser crítico é algo de fundamentalmente diferente, a saber, significa com a máxima vigilância ocupar-se que, do todo real e do verdadeiro, nada lhe escape. (Lauand, 1987, p. 95-96)

Ora, uma pessoa animada com disposições tais como as que são aqui descritas, que, sem preconceitos, se abre para a 
Research, Society and Development, v. 11, n. 3, e20311326496, 2022

(CC BY 4.0) | ISSN 2525-3409 | DOI: http://dx.doi.org/10.33448/rsd-v11i3.26496

totalidade, é alguém que em sua busca está sendo movido pela própria verdade, não pelo prazer. Uma pessoa assim não se dará por satisfeita com uma verdade qualquer. Ela como que aprendeu por antecipação a natureza de uma verdade que é capaz de justificar todas as demais verdades; uma verdade que não pode ser objeto de método experimental, mas apenas de Contemplação do Intelecto.

Assim como ocorreu neste trabalho, sugiro que mais pesquisas filosóficas sejam realizadas em conjunto com as ciências extas, no intuito de transbordar os limites do método experimental.

\section{Referências}

Agostinho, S. (1995). A Trindade. Paulus Editora.

Agostinho, S. (2017). confissões. Editora Schwarcz-Companhia das Letras.

Alonso, M. \& Finn, E.J. (1992). Physics. Editora Addison-Wesley

Aquino, T. (1937). Summa contra Gentiles. Marietti.

Aquino, T. (1955). Summa Theologiae. (volumes I-V). Iterate Edition.

Aristóteles. (1831) Física. vols. I-VII. Edição de Bekker. Academia de Ciências da Prússia.

Aristóteles. (1987) Organón. Editora Edipro.

Aristóteles. (2012) Metafísica. Editora Edipro.

Caruso, F \& Oguri, V. (2006). Física moderna: Origens Clássicas e Fundamentos Quânticos. Campus.

Chatelet, F. (1982). História da Filosofia. (Vols.1-2) Zahar, 1982.

Descartes, R. (2018) Meditações Metafísicas. Edipro. (p. 31).

Duhem, P. (1894) Quelques réflexions su sujet de la physique expérimentale, Revue des questions scientifiques. 36(8), 179-229.

Galilei, G. (1996) O ensaiador. Nova Cultural

Gilson, E. (1952) El Espíritu de la Filosofia Medieval. EMECE.

Grenz, S. J. (2008). Pós-modernismo. Vida Nova.

Infopédia Dicionário Porto Editora. (2021). https://www.infopedia.pt/.

Kant, I. (1966) Crítica da Razão Pura. Editora Edipro.

Keller, T. (2018) Deus na era secular. Vida Nova.

Landau, L. \& Lifshitz, E. (1973) Física Teórica 2 - Teoria do campo. Editora Mir.

Lauand, L. J. (1987) O que é a Universidade. Edusp-Perspectiva (pp. 96-116).

Netmundi. (2021) Descartes e o método que revolucionou o mundo moderno. https://www.netmundi.org/filosofia/2012/o-metodo-de-descartes/.

Nussenzveig, H. M. (2002) Curso de Física Básica (vol. 2). Edgard Blucher.

Philippe, M. D. (1949) Nature de l'acte de contemplation philosophique dans la perspective des principes d'Aristote, Revue Thomiste. 3, 538-539.

Rosa, A. D. P. (2000) A educação segundo a filosofia perene. 2000. Tese de mestrado Faculdade de Educação - Universidade de São Paulo.

Rosa, A. D. P. (2001) O que é vida. Edusp.

Rossetti, V. (2018) Francis Bacon e seu Método Científico. NetNature. https://netnature.wordpress.com/2018/01/08/francis-bacon-e-seu-metodo-cientifico/.

SEARA, 2021. Universidade Federal do Ceará. https://seara.ufc.br/pt/.

UNESP, 2021. Universidade Estadual Julio de Mesquita Filho. http://www.rc.unesp.br 